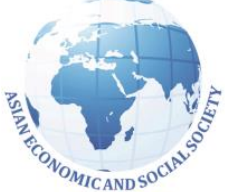

AESS

\title{
Asian Journal of Empirical Research
}

\section{ANALYSIS OF GDP TRENDS AND INEQUALITIES IN VIETNAM'S PROVINCES AND GROUPS OF PROVINCES}

\author{
Xuan-Binh Vu \\ Department of Accounting, Finance and Economics, Griffith University, Australia. \\ The Australian Research Centre for Health Services Innovation, Institute of Health and Biomedical \\ Innovation, Australia \\ Son Nghiem \\ The Australian Research Centre for Health Services Innovation, Institute of Health and Biomedical \\ Innovation, Australia

\section{Article History: \\ Received: 01-Aug-2016 \\ Revised received: 25 -Aug- \\ 2016 \\ Accepted: 05-Sep-2016 \\ Online available: 20 -Oct-} \\ 2016

\section{Keywords:} \\ Vietnam, \\ provincial GDP trends, \\ inequality, \\ foreign direct investment, \\ public investment, \\ transfers

\begin{abstract}
Our recent paper (Vu et al., 2016) applied the Phillips and Sul's method $(2007,2009)$ and found that the 61 provinces of Vietnam were formed in five convergence sub-groups. This current paper identifies trends and patterns of inequality in provincial GDP per capita of each sub-group of provinces in Vietnam during the period 1990-2011. It also analyses the growth path of each province compared with that of the reference economy [Ho Chi Minh City (HCMC) and the national average]. The results show that there were the downward trends of inequality in GDP per capita of each sub-group. Also, during the period 1990-1994, most provinces diverged from HCMC but during the period 2004-2011, all provinces tended to converge to it. However, there were few poorest provinces, which tend to be located in geographically and economically isolated regions of Vietnam. This paper analyses main characteristics of provinces and key factors affecting the trends and patterns of disparities in GDP per capita of each subgroup. Furthermore, several policy implications are discussed.
\end{abstract}

\section{INTRODUCTION}

Since the implementation of economic reform in 1986, Vietnam has attained remarkable economic achievements (Dollar, 2002; Malesky \& London, 2014). The GDP growth rate increased from $2.8 \%$ in 1986 to $9.5 \%$ in 1995 and $6.7 \%$ in 2015 (World Bank, 2016). The GDP per capita (PPP ${ }^{1}$ ) increased from US\$ 970 in 1990 to US\$ 6,022 in 2015 (World Bank, 2016). The poverty headcount ratio at US\$ 1.90 a day (2011 PPP) (\% of population) decreased from $49.2 \%$ in 1992 to $3.2 \%$ in 2012 (World Bank, 2016). However, the income inequality (Gini index) increased from 0.35 in 1992 to 0.39 in 2012 (World Bank, 2016).

Corresponding author's

Name: Xuan-Binh Vu

Email address: economics.binh@gmail.com

${ }^{1}$ Purchasing power parity 
There are few previous studies on economic growth and income inequality in Vietnam (Walle \& Gunewardena, 2001; Shankar \& Shah, 2003; Le, 2003; Takahashi, 2007; Liu, 2001, 2008; Nguyen, 2009; Le \& Booth, 2013); however, these studies show consistent evidence of rising inequality at the national level but do not analyse economic performance and income inequality at provincial level (for more details, see literature review section). We (Vu et al., 2016) applied the "log(t)" test developed by Phillips and Sul $(2007,2009)$ and found no significant evidence of overall convergence in GDP per capita across the 61 provinces in Vietnam during the period 1990-2011. Moreover, Vu et al. (2016) identified that the 61 provinces were formed in five sub-groups in which provincial GDP per capita converged (see Table 1).

This current paper is developed to identify the trends and patterns of inequality in provincial GDP per capita of each of the five convergence sub-groups in Vietnam during the period 1990-2011. It also analyses the growth path of each province compared with that of the reference economy (HCMC and the national average). Provincial characteristics and factors determining the trends and patterns of inequality in GDP per capita within each convergence sub-group are investigated in this paper.

The remainder of this paper is organised as follows. Section 2 presents the literature review on income disparity while Section 3 outlines the methodology used in this study. Section 4 describes the data used. Section 5 discusses the study's empirical results and Section 6 concludes.

Table 1: Phillips-Sul tests of overall convergence and convergence sub-group formation

\begin{tabular}{|c|c|c|c|}
\hline & Provinces & coefficient & t-stat \\
\hline Vietnam $^{*}$ & All 61 provinces & -0.543 & -16.333 \\
\hline Sub-group 1 & $\begin{array}{l}\text { Quang Ninh, Hanoi, Hai Phong, Hai Duong, Hung Yen, } \\
\text { Ninh Binh, Vinh Phuc, Bac Ninh, Da Nang, Quang Ngai, } \\
\text { Khanh Hoa, Lam Dong, Ho Chi Minh City, Tay Ninh, } \\
\text { Binh Duong, Dong Nai, Binh Thuan, Ba Ria Vung Tau, } \\
\text { Long An, Dong Thap, Kien Giang, Can Tho - Hau Giang, } \\
\text { Tra Vinh, Soc Trang, Bac Lieu, and Ca Mau. }\end{array}$ & -0.017 & -0.254 \\
\hline Sub-group 2 & $\begin{array}{l}\text { Cao Bang, Tuyen Quang, Ha Nam, Thai Binh, Thanh } \\
\text { Hoa, Quang Nam, An Giang, Tien Giang, Vinh Long, } \\
\text { and Ben Tre }\end{array}$ & 0.370 & 5.654 \\
\hline Sub-group 3 & Lang Son, Thua Thien Hue, and Binh Dinh & 0.125 & 1.053 \\
\hline Sub-group 4 & $\begin{array}{l}\text { Son La, Lao Cai, Bac Kan, Yen Bai, Thai Nguyen, Phu } \\
\text { Tho, Ha Tay, Nam Dinh, Nghe An, Ha Tinh, Phu Yen, } \\
\text { Kon Tum, Gia Lai, and Binh Phuoc }\end{array}$ & 0.300 & 2.963 \\
\hline Sub-group 5 & $\begin{array}{l}\text { Lai Chau-Dien Bien, Hoa Binh, Ha Giang, Bac Giang, } \\
\text { Quang Binh, Quang Tri, Dak Nong-Dak Lak, and Ninh } \\
\text { Thuan }\end{array}$ & -0.043 & -1.540 \\
\hline
\end{tabular}

Notes: (1) The Phillips-Sul log-t test is applied to sets of data for GDP per capita. A set of economies is considered a convergent set (or sub-group) if the log-t coefficient is positive, or if the log-t coefficient is negative but its t-statistic is > -1.65. (2) An asterisk (*) indicates a divergent economy.

Source: Vu et al. (2016)

\section{LITERATURE REVIEW}

\subsection{Vietnam}

There are few previous studies on regional income disparities in Vietnam and they show significant evidence of rising inequality. Walle \& Gunewardena (2001) investigated inequality between ethnic groups by applying the Blinder-Oaxaca decomposition technique to analyse the Vietnam Living Standard Surveys (VLSS) 1992-1993. The study found that minority ethnic groups experienced lower per capita expenditure. Takahashi (2007) and Le \& Booth (2013) also applied the BlinderOaxaca decomposition to VLSS 1992-1998 and found significant evidence of increased income 
inequality in Vietnam. Liu (2001, 2008) applied general entropy and Theil indices to measure inequality to measure inequality in Vietnam using the VLSS 1992-1993 and the VLSS 1997-1998. The authors found that the inequality in per capita expenditure increased slightly between urban and rural areas as well as between eight regions in Vietnam. Similarly, Shankar and Shah (2003) and Le (2003) found that Vietnam experienced a dramatic increase in regional income inequality, which was measured by Gini index, Theil index and the use of weighted coefficient of variation (CVW). Nguyen (2009) tested the hypothesis of convergence in income in Vietnam during the period of 1990-2006. By using the unconditional $\beta$-convergence test and the augmented Dickey-fuller (ADF) test for panel unit root, Nguyen (2009) found no significant evidence of a converging pattern. In addition, the results of using Theil index show that regional inequality increased moderately over the study period, except for the declines in 1998 and 1999.

\subsection{Other countries}

The international literature on income inequality is extensive, thus we focus on relevant studies. The literature on output convergence can be divided into firstly, a number of traditional time-series data approaches: that is, $\delta$-convergence (the reduction of dispersion across countries); $\beta$-convergence (poor countries growing faster than rich countries) and the unit-root tests. Secondly a new dynamic panel data approach developed by Phillips \& Sul (2009) is reviewed.

The $\beta$-convergence and $\delta$-convergence tests have been applied to a wide range of countries and regions: the USA (Barro \& Sala-i-Martin, 1991), EU and Japan (Sala-i-Martin, 1996), Australia (Neri, 1998; Nguyen et al., 2006; Smith, 2004), Indonesia (Garcia \& Soelistianingsih, 1998; Kharisma \& Saleh, 2013; Resosudarmo \& Vidyattama, 2006), and China (Chang, 2002; Gen, 1999; Jian et al., 1996). Barro \& Sala-i-Martin (1991) found that the rate of convergence between the poor and the rich states in the USA was approximately two percent per year in the 1880-1988 periods. Sala-i-Martin (1996) reported a similar convergence speed across the USA (1880-1990), in Japan (1955-1990), and in five European nations (1950-1990). Neri (1998) found that Australia experienced $\beta$-convergence in the 1861-1992 period but divergence trends were reported in the more recent periods 1976-1992 (Neri, 1998), 1966-2001 (Smith, 2004) and 1984-2005 (Nguyen et al., 2006).

Similar convergence tests were also applied to developing economies. Empirical evidence in Indonesia indicated convergence in a number of periods, including 1975-1993 (Garcia \& Soelistianingsih, 1998), 1993-2002 (Resosudarmo \& Vidyattama, 2006), and 1982-2008 (Kharisma $\&$ Saleh, 2013). These studies argued that improvements in human capital, accumulation of physical capital, and trade liberalisation were the main factors contributing to a trend of increasing convergence in Indonesia. However, empirical studies of regions in China showed that income inequality had increased and income levels across provinces were not converging (Jian et al., 1996).

The unit root test approach examines evidence of convergence by testing to determine whether outputs are stationary across countries or regions. Results of unit roots tests for the USA and other developed economies remained consistent with $\beta$ - and $\delta$-convergence tests. For example, in the context of the USA, Loewy \& Papell (1996), and Carlino \& Mills (1996) found significant evidence of convergence during the 1929-1990 period while Genc et al. (2011) supported evidence of a convergence trend in the period 1969-2001. However, the literature has reported less consistency in empirical results between the unit root test and $\beta$ - and $\delta$-convergence tests for developing economies. For example, studies using unit root tests for China (Pedroni \& Yao, 2006) found evidence of convergence during the 1952-1977 period and divergence in the 1978-1997 period. Meanwhile, Narayan (2008) concluded that there was possible convergence of real GDP per capita across the provinces in China during the period 1952-2003.

The most recent development in the literature on tests of output convergence is the " $\log (\mathrm{t})$ " test approach proposed by Phillips \& Sul (2007, 2009). Different from other tests, $\log (\mathrm{t})$ takes into account heterogeneity among individual regions and allows for the possibility of convergence among 
sub-groups of regions. Phillips and Sul (2009) found significant evidence of convergence in income per capita across 48 states in the USA from 1929 to 1998. A similar application using data from the 14 European countries - namely Austria, Belgium, Denmark, Finland, France, Germany, Greece, Ireland, Italy, Netherlands, Portugal, Spain, Sweden, and the UK - in the 1980-2004 period by Apergis et al. (2010) revealed two convergence sub-groups. Similarly, Bartkowska and Riedl (2012) identified six per capita income convergence sub-groups among 206 European regions between 1990 and 2002. Using an ordered logit estimator, Bartkowska and Riedl (2012) found that initial conditions such as human capital and per capita income play a crucial role in determining the formation of convergence sub-groups among the European regions. Vu (2015) analysed intercountry output disparities between the APEC countries during the period 1990 2011 and found that the countries' GDP per capita tended to diverge over the study period; however, three convergence sub-groups are identified using the Phillips-Sul's method.

The " $\log (\mathrm{t})$ " test approach has also been applied to a number of developing economies. Herrerias \& Ordonez (2012) found convergence in income per capita in five groups of provinces in China during 1952-2008. However, three provinces, Heilongjiang, Liaoning and Guizhou, formed a divergent subgroup due to their different levels of labour productivity and capital intensity. Likewise, Ghosh et al. (2013) found significant divergence in per capita income across 15 of India's major states both at the aggregate and sectoral levels during the period 1968/69-2008/09. Specifically, Ghosh et al. (2013) reported three convergence sub-groups at the aggregate level, three convergence subgroups in the industrial sector and two convergence subgroups in both the agriculture and services sectors.

In conclusion, there are a number of studies on income inequality and output convergence in countries and regions. However, to the best of our knowledge, this present paper is the first study that identifies trends and patterns of inequality in GDP per capita of each sub-group of provinces in Vietnam, and analyses the growth path of each province compared with that of the reference economy (HCMC and the national average). It is also the first paper analysing main characteristics of provinces and key factors affecting the trends and patterns of disparities in GDP per capita of each sub-group of provinces.

\section{METHODOLOGIES}

First, we use $\sigma$-convergence, Theil coefficient and Gini coefficient to measure trends and patterns of inequality in provincial GDP per capita within each of the five convergence sub-groups as identified by Vu et al. (2016). Following Sala-i-Martin (1996), $\sigma$-convergence is said to hold if the dispersion of GDP per capita across provinces falls over time. The weighted coefficient of variation $\left(C V_{W}\right)$ is computed as:

$$
C V_{W}=\frac{\sqrt{\sum_{i}\left(y_{i}-\bar{y}\right)^{2} \frac{p_{i}}{P}}}{\bar{y}}
$$

where $y_{i}$ is the GDP per capita of province $i ; \bar{y}$ is the mean GDP per capita of sub-group $\mathrm{j} ; P$ is the total population of sub-group $\mathrm{j}$; and $p_{i}$ is the population of province $i . C V_{W}$ was argued to diminish the degree to which smaller provinces can skew the measure of inequality (Williamson, 1965). It varies from zero for perfect equality to $\sqrt{\frac{P-p_{i}}{p_{i}}}$ for perfect inequality where province $i$ has all the GDP.

As indicated by Theil (1967), Theil coefficient is calculated as:

$$
T=\sum_{i} x_{i} \log \left(\frac{x_{i}}{q_{i}}\right)
$$

where $x_{i}$ is the GDP share of province $i$ in sub-group $\mathrm{j} ; q_{i}$ is the population share of province $i$ in subgroup j. $T$ varies from zero for perfect equality to $\log \left(P / p_{i}\right)$ for perfect inequality. 
According to Kakwani (1980) and Shankar and Shah (2003), the weighted Gini index is computed as:

$$
G_{W}=\left(\frac{1}{2 \bar{y}}\right) \sum_{i}^{n} \sum_{k}^{n}\left|y_{i}-y_{k}\right| \frac{p_{i} p_{k}}{P^{2}}
$$

where $\bar{y}$ is the mean GDP per capita of sub-group $\mathrm{j} ; P$ is the population of sub-group $\mathrm{j} ; n$ is the number of provinces within sub-group $\mathrm{j}$; and $p_{i}$ and $p_{k}$ are the population of provinces $i$ and $k$, respectively. $G_{W}$ varies from zero for perfect equality to $1-\frac{p_{i}}{p_{k}}$ for perfect inequality.

Second, in recognition of the fact that the Phillips-Sul (2007, 2009)'s methods do not allow for structural breaks, we explore the effects of structural breaks in inequality in GDP per capita using a regression-based approach by Nguyen et al. (2006). We argue that the removal of the US embargo in 1995 and major policy changes in 2004 are possible structure breaks to the Vietnamese economy. The standard method developed by Chow (1960) is used to test for possible structural breaks of the $C V_{W}$ of provincial GDP per capita around 1995 and 2004.

$$
C V w=a+b^{*} t+\varepsilon_{t}
$$

where $C V_{W}$ is the weighted coefficient of variation of the 61 provinces of Vietnam and $t$ is time variable (see Appendix C).

The results of Chow (1960)'s test show that at the 5\% level of significance, F-statistic test $(4,16)$ for the breakpoints in 1995 and 2004 [F-statistic $(4,16)=335.39]$ is greater than F-critical [F-critical (4, $16)=3.06]$. The results suggest that there are two breaks of the $C V w$ of provincial GDP per capita in 1995 and 2004.

Denoting these sub-periods 1,2 , and 3, the analysis of relative income growth paths is formulated as:

$$
\log \left(\frac{y_{i t}}{y_{t}^{*}}\right)=a_{1}+b_{1} * T R N D_{1}+a_{2} * D A_{2}+b_{2} * T R N D_{2}+a_{3} * D A_{3}+b_{3} * T R N D_{3}+\varepsilon_{i t}
$$

where $y_{i t}$ is GDP per capita of province $i$, year $t ; y_{t}^{*}$ is GDP per capita of the reference economy year $t$ : Ho Chi Minh City or the national average; $a_{j}(j=1,2,3)$ are constant intercept terms; $D A_{2}$ and $D A_{3}$ are dummy variable for two periods 1995-2004, and 2005-2011 (the first period 1990-1994 is selected as the reference period); $b_{j}(j=1,2,3)$ are slopes; and $T R N D_{j}(j=1,2,3)$ are the time trends for the three sub-periods.

Third, this paper uses descriptive analyses based on data and information collected from the General Office Statistics (GSO), the Ministry of Finance (MOF), and the Ministry of Planning and Investment (MPI) to discuss main characteristics of provinces and factors determining the trends and patterns of inequality in provincial GDP per capita within each of the five sub-groups in Vietnam.

\section{DATA SOURCES}

The data used in this paper comprised real GDP per capita at 1994 price for the 64 provinces of Vietnam during the period 1990-2011, and which were collected from the GSO. We used fixed 1994 price to control for effects of inflation. Annual data for population, overseas export, and agriculture, forestry and fishery sector at the provincial level during the period 1990-2011 were available from the GSO. Yearly data from 1990 to 2011 for public investment and foreign direct investment were collected from the MPI. Annual data on transfers from the central authority to provincial budgets were obtained from the MOF. 
As three of the 64 provinces, namely Dien Bien, Dak Nong and Hau Giang were established in 2004, the data of these three provinces were combined with data of their former sibling-provinces and thus, the final data set includes only 61 provinces.

\section{FINDINGS}

As indicated in Table 1, sub-group 1 comprises 26 provinces. The results of measuring inequality in GDP per capita across the 26 provinces show that the inequality increased during the sub-period 1990-1997, and decreased during the sub-period 1998-2011 (see Figure 1). For example, the $C V_{W}$ increased from 0.49 in 1990 to 0.58 in 1997. It then decreased slightly between 1998 and 2003 before declining considerably to 0.34 in 2011 .

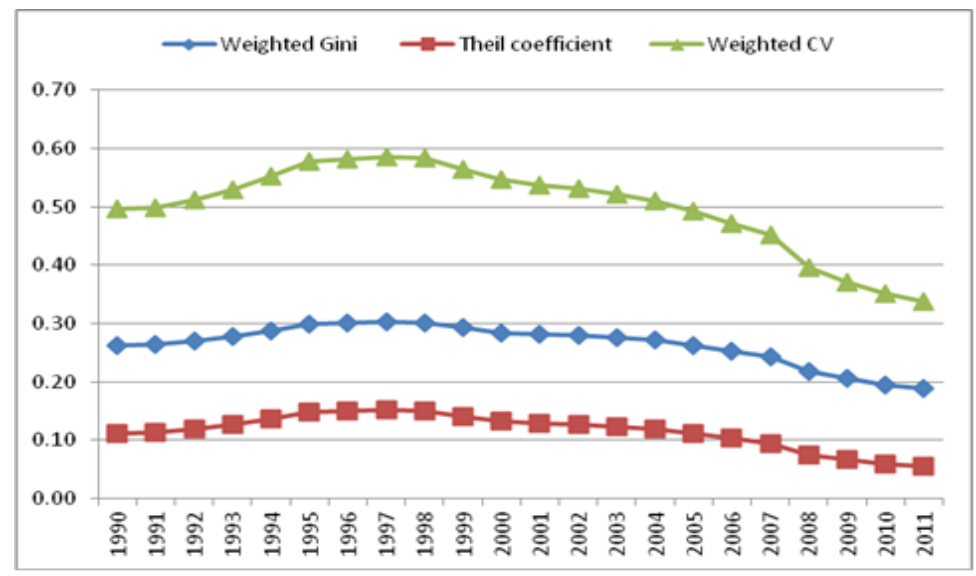

Figure 1: The inequality in GDP per capita across the 26 provinces in sub-group 1

Source: Authors' calculation

One of the main reasons leading to the trends of disparity in provincial GDP per capita of sub-group 1 was that FDI of this sub-group was allocated more evenly across the 26 provinces after 1997 . For example, in 1996, 81\% of the total FDI of sub-group 1 was allocated in its five richest cities/provinces (including Hanoi, Hai Phong, Ho Chi Minh City, Binh Duong and Dong Nai). However, in 2011, FDI of these five richest cities/provinces accounted for $73 \%$ of the total FDI of this sub-group. After 1997, the remaining provinces of sub-group 1 such as QuangNinh, Hai Duong, Hung Yen, Vinh Phuc, Bac Ninh, Da Nang, Quang Ngai, Tay Ninh, Long An and Can Tho-Hau Giang attracted more FDI. For instance, the FDI per capita at 1994 price of Vinh Phuc and Tay Ninh increased dramatically from about VND 58 thousand and VND 17 thousand in 1998 to VND 717 thousand and VND 1,140 thousand in 2011, respectively.

Table 2 shows the main characteristics of 26 provinces in sub-group 1. A majority of provinces in this sub-group have relatively high GDP per capita. For example, in 2011, 16 of the 26 provinces had higher GDP per capita compared with the national average. In addition, nine of the provinces (including Quang Ninh, Hanoi, Hai Phong, Vinh Phuc, Da Nang, HCMC, Binh Duong, Dong Nai and Ba Ria-Vung Tau) are most industrialised cities/provinces in Vietnam. For instance, in 2011, the share of agriculture, forestry and fishery to GDP of Hanoi, HCMC, Binh Duong and Ba Ria-Vung Tau were only approximately 5.8\%, $1.2 \%, 4.1 \%$ and $5.6 \%$, respectively. They are also biggest exporting performers in comparison with other provinces. For instance, in 2011, the percentage of overseas exports to GDP of Quang Ninh, HCMC, Binh Duong and Dong Nai were roughly 109\%, $126 \%, 360 \%$ and $206 \%$, respectively. 
In contrast, Table 2 shows that six provinces of sub-group 1 (including Dong Thap, Kien Giang, Tra Vinh, Soc Trang, Bac Lieu and Ca Mau) had the higher share of agriculture, forestry and fishery to GDP compared with the national average due to their comparative advantages in geographical locations and weather. Eight of the 26 provinces of sub-group 1 (comprising Quang Ninh, Hanoi, Vinh Phuc, Da Nang, Khanh Hoa, HCMC, Binh Duong, Dong Nai and Ba Ria-Vung Tau) are main revenue contributors to the budget of the central government. For example, in 2011, real transfers per capita of Hanoi, HCMC and Binh Duong to the central budget were approximately VND 1,240 thousand, VND 2,225 thousand and VND 1,694 thousand, respectively.

Appendix A contains the several results of time-series tests comparing the logarithm of GDP per capita of each province and that of Ho Chi Minh City. Appendix B, similarly lists the comparison of the logarithm of GDP per capita between each province and the national average. As indicated in Appendix A, the results show that during the sub-period 1990-1994, a majority of provinces of subgroup 1 (excluding Hanoi, Hai Phong, Lam Dong and Dong Thap) tended to diverge downward. In contrast, from 1995 to 2003,14 of the 26 provinces of this sub-group converged upward, while three provinces (including Dong Thap, Lam Dong and Long An) kept falling behind. However, during the sub-period 2004-2011, all provinces of sub-group 1 tended to converge upward. A notable point is that for the whole period 1990-2011, Dong Nai had a tendency of upward convergence. The results in Appendix B indicate that during the sub-period 1990-1994, 11 of the 26 provinces of sub-group 1 tended to diverge downward, while Hanoi, Hai Phong, HCMC, Binh Duong and Dong Nai diverged upward. Between 1995 and 2003, ten of the 26 provinces of sub-group 1 diverged from the national average. However, during the sub-period 2004-2011, a majority of provinces of sub-group 1 converged toward. Only four provinces (including QuangNinh, Tay Ninh, Kien Giang and Ca Mau) diverged upward, while Ha Duong diverged downward during the last sub-period.

Of particular interest is that only Ba Ria-Vung Tau started out with a higher GDP per capita than that of HCMC. This was mainly because of Ba Ria-Vung Tau's oil resources. In relation to HCMC, the result in Appendix A shows that during the sub-period 1990-1994 and 2004-2011, Ba Ria-Vung Tau had tendency of downward convergence with HCMC but tended to diverge upward from 1995 to 2003. When comparing Ba Ria-Vung Tau with the national average, Ba Ria-Vung Tau diverged upward between 1995 and 2003, while it then converged downward from 2004 to 2011.

An analysis of ratios of GDP per capita of each province in sub-group 1 to that of HCMC suggests that Vinh Phuc, Bac Ninh, Dong Nai and Binh Duong have been strongest performers. For instance, in Figure 2, HCMC is presented by a horizontal line at $100 \%$, while Vinh Phuc is shown as most clearly catching up with HCMC, from approximately 20\% of HCMC in 1990 to $66 \%$ in 2011. Similarly, the ratio of GDP per capita of Bac Ninh relative to that of HCMC increased dramatically from $25 \%$ in 1990 to $51 \%$ in 2011. In addition, this Figure indicates that QuangNinh, Hai Phong, Da Nang and Tay Ninh have been very strong performing provinces. 
Asian Journal of Empirical Research, 6(7)2016: 167-186

Table 2: Main economic indicators of provinces in sub-group 1

\begin{tabular}{|c|c|c|c|c|c|c|}
\hline Provinces & $\begin{array}{l}\text { GDP per capita } \\
\text { in } 2011 \text { at } 1994 \\
\text { price }(V N D \\
\text { thousand) } \\
\end{array}$ & $\begin{array}{c}\text { Ranking of } \\
\text { provincial GDP } \\
\text { per capita in } 2011\end{array}$ & $\begin{array}{c}\text { Average } \\
\text { population in } \\
2011 \\
\text { (thousand) } \\
\end{array}$ & $\begin{array}{c}\text { Percentage of } \\
\text { agriculture, forestry } \\
\text { and fishery to GDP } \\
\text { in } 2011(\%) \\
\end{array}$ & $\begin{array}{c}\text { Percentage of } \\
\text { overseas exports to } \\
\text { GDP in } 2011(\%)\end{array}$ & $\begin{array}{c}\text { Transfers per } \\
\text { capita in } 2011 \text { at } \\
1994 \text { price (VND } \\
\text { thousand) } \\
\end{array}$ \\
\hline Quang Ninh & $12,669.07$ & 11 & $1,163.7$ & 6.21 & 108.93 & -3.49 \\
\hline Hanoi & $17,179.35$ & 3 & $3,751.89$ & 5.80 & 63.31 & $-1,240.87$ \\
\hline Hai Phong & $14,187.06$ & 7 & $1,878.50$ & 9.83 & 56.87 & 125.88 \\
\hline Hai Duong & $8,545.58$ & 26 & $1,718.90$ & 23.03 & 42.75 & 125.64 \\
\hline Hung Yen & $8,980.95$ & 23 & $1,150.40$ & 23.00 & 46.84 & 341.46 \\
\hline Ninh Binh & $8,972.18$ & 24 & 906.90 & 15.00 & 6.69 & 934.25 \\
\hline Vinh Phuc & $14,495.74$ & 5 & $1,014.60$ & 15.45 & 25.33 & -839.31 \\
\hline Bac Ninh & $11,325.38$ & 14 & $1,060.30$ & 7.75 & 12.06 & 200.44 \\
\hline Đa Nang & $13,780.49$ & 8 & 951.70 & 3.80 & 44.64 & -7.49 \\
\hline Quang Ngai & $7,620.05$ & 30 & $1,221.60$ & 18.80 & 7.34 & 396.55 \\
\hline Khanh Hoa & $11,337.47$ & 13 & $1,174.10$ & 12.90 & 38.98 & -242.42 \\
\hline Lam Đong & $11,166.11$ & 16 & $1,218.70$ & 46.36 & 23.99 & 531.48 \\
\hline Ho Chi Minh City & $22,127.48$ & 2 & $7,521.10$ & 1.23 & 126.39 & $-2,225.51$ \\
\hline Tay Ninh & $13,686.54$ & 9 & $1,080.70$ & 44.48 & 49.07 & 198.13 \\
\hline Binh Duong & $14,442.47$ & 6 & $1,292.12$ & 4.14 & 360.37 & $-1,694.14$ \\
\hline Đong Nai & $15,394.78$ & 4 & $2,665.10$ & 7.50 & 206.47 & -683.17 \\
\hline Binh Thuan & $7,156.87$ & 31 & $1,180.30$ & 20.17 & 15.20 & 344.71 \\
\hline Ba Ria - Vung Tau & $54,476.92$ & 1 & $1,027.20$ & 5.61 & 111.02 & $-1,743.07$ \\
\hline Long An & $9,891.52$ & 18 & $1,449.60$ & 35.72 & 60.57 & 244.76 \\
\hline Đong Thap & $9,756.15$ & 19 & $1,673.20$ & 50.26 & 30.12 & 379.50 \\
\hline Kien Giang & $12,280.38$ & 12 & $1,714.10$ & 46.66 & 26.22 & 404.11 \\
\hline Can Tho - Hau Giang & $9,933.81$ & 17 & $1,969.50$ & 15.65 & 41.53 & 259.19 \\
\hline Tra Vinh & $9,206.81$ & 21 & $1,012.60$ & 62.15 & 14.67 & 942.18 \\
\hline Soc Trang & $9,693.06$ & 20 & $1,303.70$ & 52.36 & 30.61 & 737.76 \\
\hline Bac Lieu & $11,251.55$ & 15 & 873.30 & 51.70 & 24.44 & 607.33 \\
\hline $\mathrm{Ca} \mathrm{Mau}$ & $13,259.92$ & 10 & $1,214.90$ & 38.77 & 62.33 & 356.30 \\
\hline Vietnam & $10,550.10$ & & $1,431.18$ & 22.02 & 70.05 & 365.67 \\
\hline
\end{tabular}

(Source: Authors' calculation) 


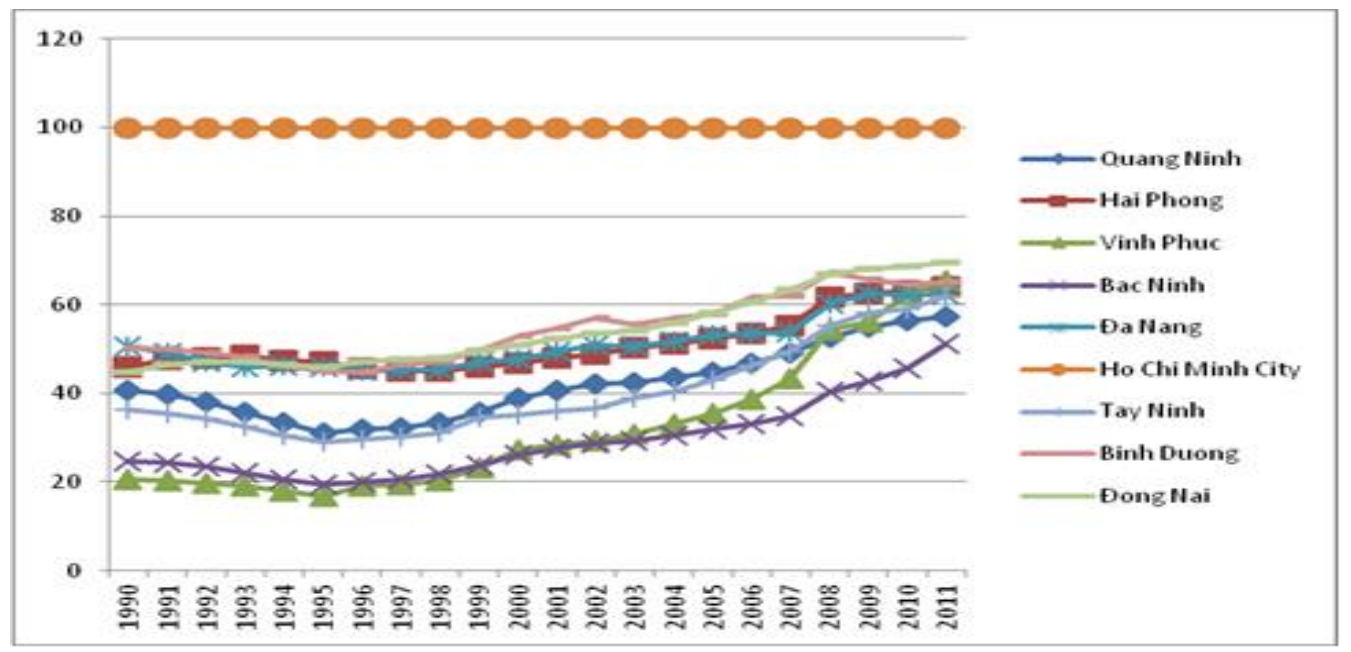

Figure 2: GDP per capita of strong performing provinces in sub-group 1 relative to that of Ho Chi Minh City (Ho Chi Minh City = 100)

(Source: Authors' calculation)

Figure 3 shows that the ranking of ratios of GDP per capita of Vinh Phuc and Bac Ninh to that of HCMC (smallest to biggest) increased significantly from 1990 to 2011. For example, the ranking of ratio of GDP per capita of Vinh Phuc to that of HCMC surged from one in 1990 to 22 in 2011.

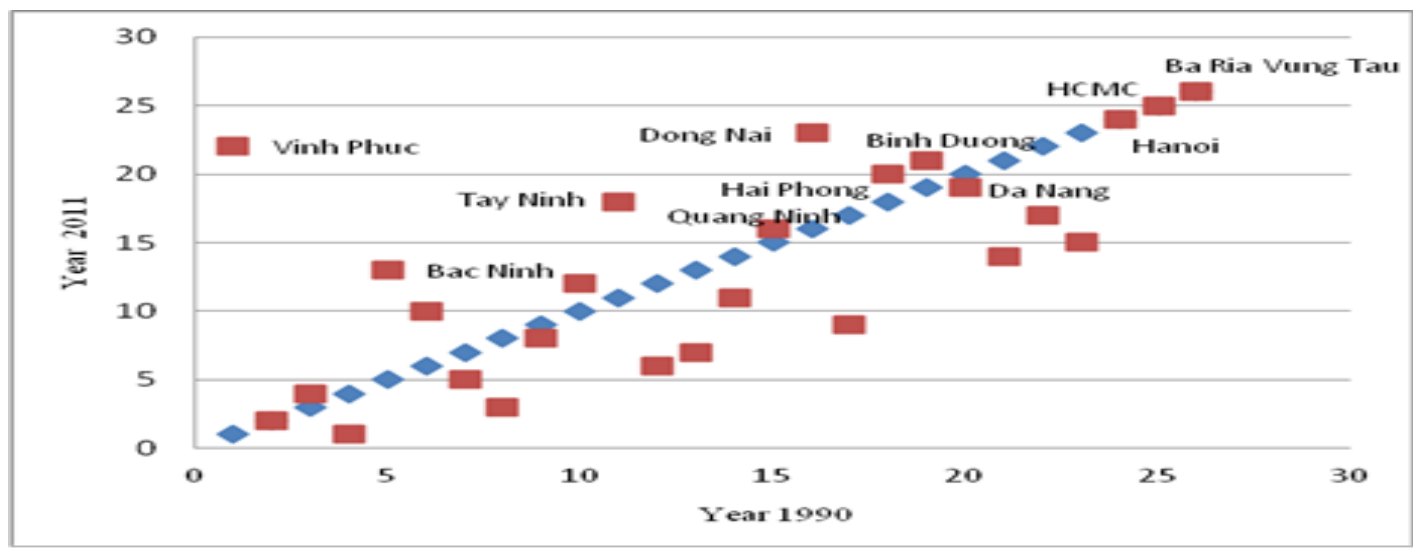

Figure 3: Ranking of ratios of GDP per capita of each province in sub-group 1 to that of CMC (smallest to biggest)

(Source: Authors' calculation)

One of the main reasons leading to very strong performance of Binh Duong, Dong Nai and Tay Ninh was that these provinces have strong economic ties with Vietnam's commercial capital (HCMC) or in the case of Vinh Phuc and Bac Ninh with Vietnam's administrative capital (Hanoi). In addition, table 2 highlights the strength and importance of Quang Ninh, Hai Phong and Da Nang as regional or local economic centres, as well as the benefits of proximity to such centres. Furthermore, the strong performance of those provinces could be resultant from substantial FDI in their administrative areas, especially during the period 2004-2011. For example, the FDI per capita at 1994 price of Bac Ninh and Da Nang increased dramatically from VND 23 thousand and VND 730 thousand in 2004, to VND 1,276 thousand and VND 1,029 thousand in 2011, respectively. 
Sub-group 2 includes ten provinces: Cao Bang, Tuyen Quang, Ha Nam, Thai Binh, Thanh Hoa, Quang Nam, An Giang, Tien Giang, Vinh Long and Ben Tre. Figure 4 shows movements over time of three measures of inequality in GDP per capita: the $C V_{W}$, Theil coefficient and Gini coefficient. As can be seen from this figure, the $C V_{W}$, Theil coefficient and Gini coefficient tended to increase slightly from 1990 to 1995 . They then decreased between 1996 and 2011. For example, the $C V_{W}$ increased from approximately 0.20 in 1990 to 0.22 in 1995 before declining to 0.12 in 2011 .

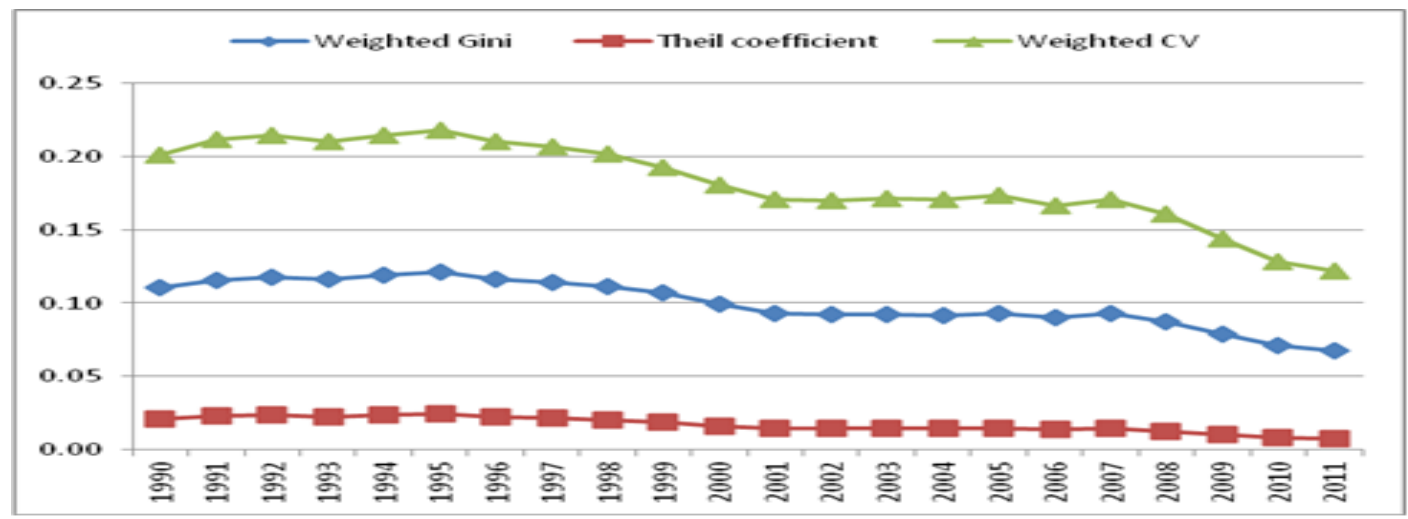

Figure 4: Coefficient of variation $\left(C V_{W}\right)$, Theil coefficient and Gini coefficient of GDP per capita at 1994 price of provinces in sub-group 2

(Source: Authors' calculation)

One of the most important reasons resulting in the decline in the disparities in GDP per capita across provinces of sub-group 2 was that poorer provinces in this sub-group received significant subsidies from the central government through its public investment and poverty reduction programs. For instance, the Tuyen Quang Hydroelectric Plant was built during the period 2002-2008 with total investment VND 7,500 billion, accounting for approximately $112 \%$ of the nominal GDP of Tuyen Quang in 2008. In addition, Cao Bang, Thanh Hoa and Quang Nam were subsidised significantly through Nationally Targeted Programs such as the Hunger Eradication and Poverty Reduction Programme and the Programme for socio-economic Development in Communes facing Extreme Hardship in ethnic minority and mountainous areas.

Table 3 shows main characteristics of provinces of sub-group 2. In 2011, all ten provinces of this sub-group had lower GDP per capita compared with the national average. In addition, they are agricultural provinces in which some of them (including Thai Binh, An Giang, Tien Giang, Vinh Long and Ben Tre) have advantages of agriculture and fishery production. For example, in 2011, the percentages of agriculture, forestry and fishery to GDP of Tien Giang, Vinh Long and Ben Tre were approximately $47 \%, 50 \%$ and $51 \%$, respectively. Also, four of the 10 provinces of sub-group 2 are significant subsidy recipients from the central budget. For instance, in 2011, transfers per capita at 1994 price from the central government to Cao Bang and Tuyen Quang were approximately VND 2,415 thousand and VND 1,077 thousand, respectively.

The results in Appendix A indicate that from 1990 to 1994 all 10 provinces of sub-group 2 diverged from HCMC, and five of them kept falling behind between 1995 and 2003. In contrast, during the last period 2004-2011, all provinces of this sub-group had a propensity to catch up with HCMC. In relation to the national average, the results in Appendix B show that between 1990 and 2003 almost all provinces of sub-group 2 diverged downward. However, from 2004 to 2011, a majority of them converged upward toward the national average. 
Table 3: A set of economic indicators of provinces of sub-group 2

\begin{tabular}{lcccccc}
\hline Provinces & $\begin{array}{c}\text { GDP per } \\
\text { capita in } \\
\mathbf{2 0 1 1} \text { at } \\
\mathbf{1 9 9 4} \text { price } \\
\text { (VND } \\
\text { thousand) }\end{array}$ & $\begin{array}{c}\text { Ranking of } \\
\text { provincial } \\
\text { GDP per } \\
\text { capita in } \\
\text { Vietnam in } \\
\mathbf{2 0 1 1}\end{array}$ & $\begin{array}{c}\text { Average } \\
\text { population } \\
\text { in 2011 } \\
\text { (Thousand) }\end{array}$ & $\begin{array}{c}\text { Percentage of } \\
\text { agriculture, } \\
\text { forestry and } \\
\text { fishery to GDP } \\
\text { in 2011 (\%) }\end{array}$ & $\begin{array}{c}\text { Percentage of } \\
\text { overseas } \\
\text { exports to } \\
\text { GDP in 2011 } \\
\text { (\%) }\end{array}$ & $\begin{array}{c}\text { Transfers per } \\
\text { capita in 2011 } \\
\text { at 1994 price } \\
\text { (VND } \\
\text { thousand) }\end{array}$ \\
\hline Cao Bang & $6,361.50$ & 40 & 515.00 & 33.31 & 5.03 & $2,415.66$ \\
Tuyen Quang & $6,538.82$ & 37 & 730.80 & 37.47 & 1.10 & $1,077.09$ \\
Ha Nam & $7,785.74$ & 29 & 786.90 & 20.05 & 23.93 & 665.05 \\
Thai Binh & $7,040.31$ & 33 & $1,786.00$ & 37.26 & 19.19 & 478.29 \\
Thanh Hoa & $6,689.27$ & 36 & $3,412.60$ & 23.84 & 5.66 & 788.58 \\
Quang Nam & $7,113.48$ & 32 & $1,435.00$ & 20.67 & 22.31 & 754.93 \\
An Giang & $8,698.47$ & 25 & $2,151.00$ & 33.74 & 33.63 & 228.36 \\
Tien Giang & $8,996.41$ & 22 & $1,682.60$ & 47.19 & 30.59 & 222.91 \\
Vinh Long & $8,356.69$ & 28 & $1,028.60$ & 49.93 & 19.06 & 268.33 \\
Ben Tre & $8,461.92$ & 27 & $1,257.80$ & 50.75 & 18.53 & 376.93 \\
Vietnam & $10,550.10$ & & $1,431.18$ & 22.02 & 70.05 & 365.67 \\
\hline
\end{tabular}

(Source: Authors' calculation)

Sub-group 3 consists of Lang Son, Thua Thien Hue and Binh Dinh. Figure 7 shows that the $C V_{W}$, Theil coefficient and Gini coefficient fluctuated slightly from 1990 to 1993, and then peaked in 1995 before falling afterwards (except 2004 and 2005). For instance, the $C V_{W}$ fluctuated around 0.05 between 1990 and 1993, reached a peak at 0.097 in 1995 before falling to 0.047 in 2011.

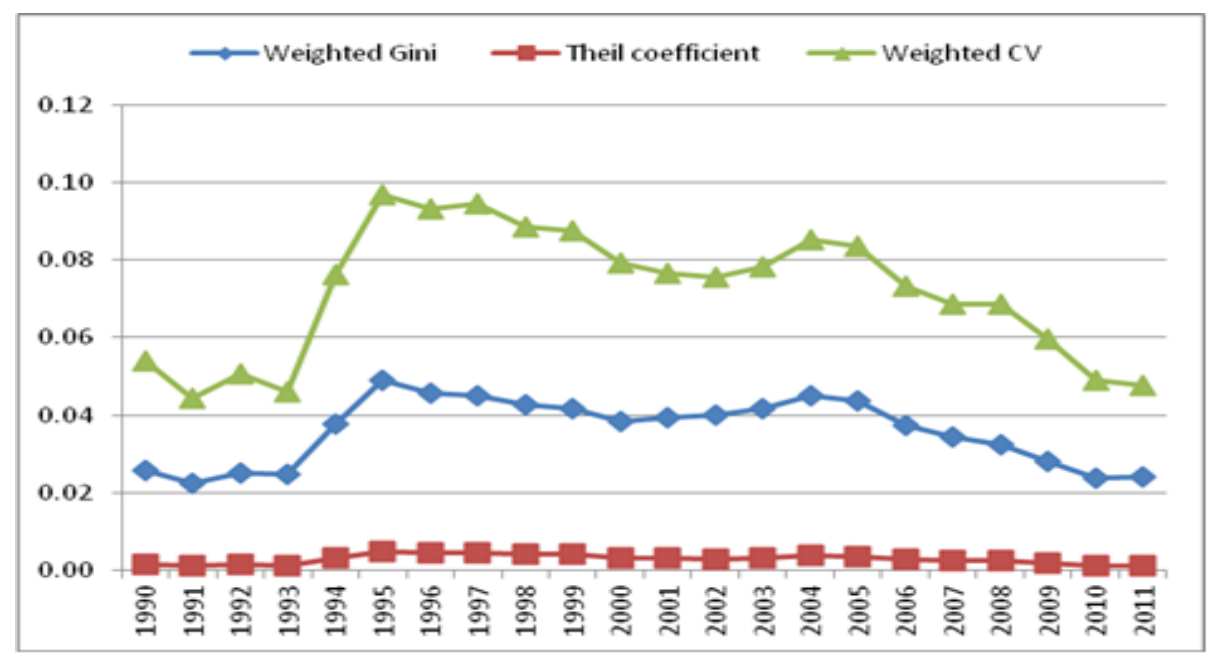

Figure 7: Coefficient of variation $\left(C V_{W}\right)$, Theil coefficient and Gini coefficient of GDP per capita at 1994 price across provinces in sub-group 3

(Source: Authors' calculation)

Table 4 indicates that in 2011, GDP per capita of all provinces in sub-group 3 were approximately two-thirds of the national average. In 2011, the percentage of agriculture, forestry and fishery to GDP of Lang Son and Binh Dinh were higher than the national average. All the provinces received significant subsidies from the central government. For example, in 2011, transfers per capita from the central government of Lang Son were roughly 3.5 times of the national average. 
Table 4: A set of economic indicators of provinces in sub-group 3

\begin{tabular}{|c|c|c|c|c|c|c|}
\hline Provinces & $\begin{array}{c}\text { GDP per } \\
\text { capita in } \\
2011 \text { at } 1994 \\
\text { price (VND } \\
\text { thousand) } \\
\end{array}$ & $\begin{array}{c}\text { Ranking of } \\
\text { provincial GDP } \\
\text { per capita in } \\
\text { Vietnam in } 2011\end{array}$ & $\begin{array}{c}\text { Average } \\
\text { population } \\
\text { in } 2011 \\
\text { (Thousand) }\end{array}$ & $\begin{array}{l}\text { Percentage of } \\
\text { agriculture, } \\
\text { forestry and } \\
\text { fishery to GDP } \\
\text { in } 2011(\%) \\
\end{array}$ & 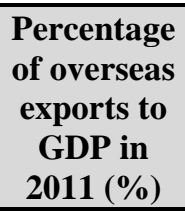 & $\begin{array}{c}\text { Transfers } \\
\text { per capita in } \\
2011 \text { at } 1994 \\
\text { price }(V N D \\
\text { thousand) }\end{array}$ \\
\hline$\overline{\text { Lang }}$ & $6,769.65$ & 35 & & 3770 & 5.39 & $1,337.35$ \\
\hline Thua Thien Hue & 6,18 & 42 & 10 & 0 & 13.10 & .31 \\
\hline Binh Đinh & $6,895.68$ & 34 & $1,497.30$ & 36.30 & 34.29 & 319.80 \\
\hline Vietnam & $10,550 \cdot 10$ & & $1,431.18$ & 22.02 & 70.05 & 365.67 \\
\hline
\end{tabular}

(Source: Authors' calculation)

The results in Appendix A indicate that from 1990 to 1994, all provinces of sub-group 3 diverged from HCMC; however, they tended to converge with HCMC between 2004 and 2011. When comparing the provinces of sub-group 3 with the national average, the results in Appendix B indicate that between 1990 and 1994, Lang Son and Thua Thien Hue diverged downward, while only Lang Son kept falling behind from 2004 to 2011. In contrast, Thua Thien Hue and Binh Dinh tended to converge upward during the last period 2004-2011.

Sub-group 4 comprises 14 provinces: Son La, Lao Cai, Bac Kan, Yen Bai, Thai Nguyen, Phu Tho, Ha Tay, Nam Dinh, Nghe An, Ha Tinh, Phu Yen, Kon Tum, Gia Lai and Binh Phuoc. Figure 8 shows that the $C V_{W}$, Theil coefficient and Gini coefficient fluctuated slightly from 1990 to 2003. They then decreased quickly before remaining almost unchanged between 2009 and 2011. For example, the $C V_{W}$ fluctuated at approximately 0.12 between 1990 and 2003. It then declined to 0.08 in 2009 before remaining stable at that level until 2011.

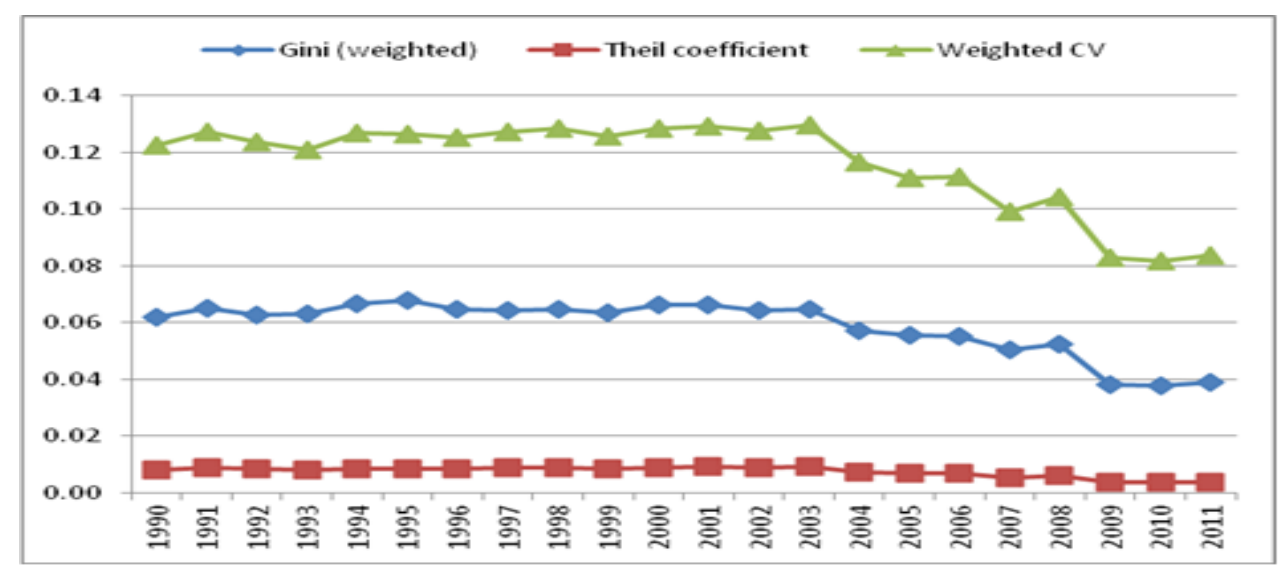

Figure 8: Coefficient of variation $\left(C V_{W}\right)$, Theil coefficient and Gini coefficient of GDP per capita at 1994 price of the provinces in sub-group 4

(Source: Authors' calculation)

One of the main reasons for the decline in the disparities in GDP per capita of sub-group 4 after 2003 was that five poorer provinces including Lao Cai, Bac Kan, Yen Bai, Ha Tinh and Kon Tum received more subsidies from the central government after the 2002 State Budget Law which came into effect in 2004 ( Vu, 2015). Another reason could be the huge investment in the hydro-electronic power plant of Son La (one of the poorest province) during the period 2005-2012. In particular, the total investment in this project was about VND 60,196 billion, accounting for approximately 6.5 times of the nominal GDP of Son La province in 2008. 
Table 5 indicates that in 2011, all provinces of sub-group 4 had lower GDP per capita compared with the national average. In contrast, almost all provinces of this sub-group have higher ratio of agriculture, forestry and fishery to GDP than the national average. For example, in 2011, the ratios of agriculture, forestry and fishery to GDP of Son La and Binh Phuoc were approximately $45 \%$ and $49 \%$, respectively. Of a notable point is that in 2011 the percentage of overseas exports to GDP of Binh Phuoc was much higher than those of other provinces. This was because Binh Phuoc had advantages of rubber, cashew nuts and pepper. In 2011, all provinces in sub-group 4 still received considerable subsidies from the central government. For instance, in 2011, real transfer per capita of Bac Kan were VND 2,259 thousand, accounting for roughly 50\% of its GDP per capita.

Table 5: A set of economic indicators of provinces of sub-group 4

\begin{tabular}{lcccccc}
\hline Provinces & $\begin{array}{c}\text { GDP per } \\
\text { capita in } \\
\mathbf{2 0 1 1} \text { at 1994 } \\
\text { price (VND } \\
\text { thousand) }\end{array}$ & $\begin{array}{c}\text { Ranking of } \\
\text { provincial } \\
\text { GDP per } \\
\text { capita in } \\
\text { Vietnam in } \\
\mathbf{2 0 1 1}\end{array}$ & $\begin{array}{c}\text { Population } \\
\text { in 2011 } \\
\text { (Thousand) }\end{array}$ & $\begin{array}{c}\text { Percentage of } \\
\text { agriculture, } \\
\text { forestry and } \\
\text { fishery to } \\
\text { GDP in 2011 } \\
(\boldsymbol{\%})\end{array}$ & $\begin{array}{c}\text { Percentage } \\
\text { of overseas } \\
\text { exports to } \\
\text { GDP in } \\
\mathbf{2 0 1 1}(\boldsymbol{\%})\end{array}$ & $\begin{array}{c}\text { Transfers per } \\
\text { capita in 2011 } \\
\text { at 1994 price } \\
\text { (VND } \\
\text { thousand) }\end{array}$ \\
\hline Son La & $4,314.80$ & 58.00 & $1,119.40$ & 44.54 & 1.23 & 981.48 \\
Lao Cai & $5,327.06$ & 55.00 & 637.50 & 28.27 & 15.71 & $1,343.69$ \\
Bac Kan & $4,945.29$ & 56.00 & 298.70 & 42.03 & 2.72 & $2,259.35$ \\
Yen Bai & $5,643.62$ & 52.00 & 758.60 & 32.90 & 3.93 & $1,425.43$ \\
Thai Nguyen & $6,106.81$ & 45.00 & $1,139.40$ & 21.28 & 14.45 & 590.24 \\
Phu Tho & $6,064.73$ & 46.00 & $1,326.00$ & 26.74 & 34.64 & 881.39 \\
Ha Tay & $5,853.43$ & 50.00 & $2,809.34$ & 24.51 & 8.00 & 375.20 \\
Nam Đinh & $6,393.28$ & 38.00 & $1,833.50$ & 28.80 & 18.43 & 511.19 \\
Nghe An & $6,146.97$ & 43.00 & $2,942.90$ & 27.06 & 7.83 & 666.19 \\
Ha Tinh & $6,133.63$ & 44.00 & $1,229.30$ & 35.86 & 6.86 & $1,088.23$ \\
Phu Yen & $6,034.35$ & 47.00 & 871.90 & 28.78 & 15.29 & 474.86 \\
Kon Tum & $6,367.94$ & 39.00 & 453.20 & 32.47 & 15.13 & $1,639.16$ \\
Gia Lai & $5,752.13$ & 51.00 & $1,322.00$ & 43.97 & 18.75 & 553.80 \\
Binh Phuoc & $6,008.29$ & 48.00 & 905.30 & 49.46 & 51.19 & 239.29 \\
Vietnam & $10,550.10$ & & $1,431.18$ & 22.02 & 70.05 & 365.67 \\
\hline
\end{tabular}

(Source: Authors' calculation)

In the relation to HCMC, the results in Appendix A indicate that from 1990 to 1994, all provinces of sub-group 4 diverged downward. During the sub-period 1995-2003, six provinces (including Bac Kan, Yen Bai, Thai Nguyen, Phu Tho, Nghe An and Kon Tum) converged upward, while Lao Cai, Nam Dinh and Binh Phuoc continued falling behind. However, from 2004 to 2011, all provinces of this sub-group had a tendency to catch up with HCMC. When comparing provinces with the national average, the results in Appendix B show that between 1990 and 1994, almost all provinces of subgroup 4 (excluding Son La) diverged downward. During the sub-period 1995-2003, eight of the 14 provinces of this sub-group kept falling behind, while only Phu Tho converged upward. In contrast, from 2004 to 2011, half of the 14 provinces tended to converge upward, while Ha Tay continued falling behind.

Sub-group 5 consists of eight provinces: Lai Chau-Dien Bien, Hoa Binh, Ha Giang, Bac Giang, Quang Binh, Quang Tri, Dak Nong-Dak Lak and Ninh Thuan. Figure 9 shows that during the subperiod 1990-2005 the inequality in GDP per capita across provinces of sub-group 5 tended to decrease but then increased slightly until 2011. For example, the $C V_{W}$ decreased from 0.34 in 1990 to 0.16 in 2005 before increasing slightly to 0.19 in 2011 . The decreased trend in the inequality between the provinces of sub-group 5 could be resultant from the very significant transfers of the central government to Ha Giang, Lai Chau-Dien Bien and Hoa Binh. 


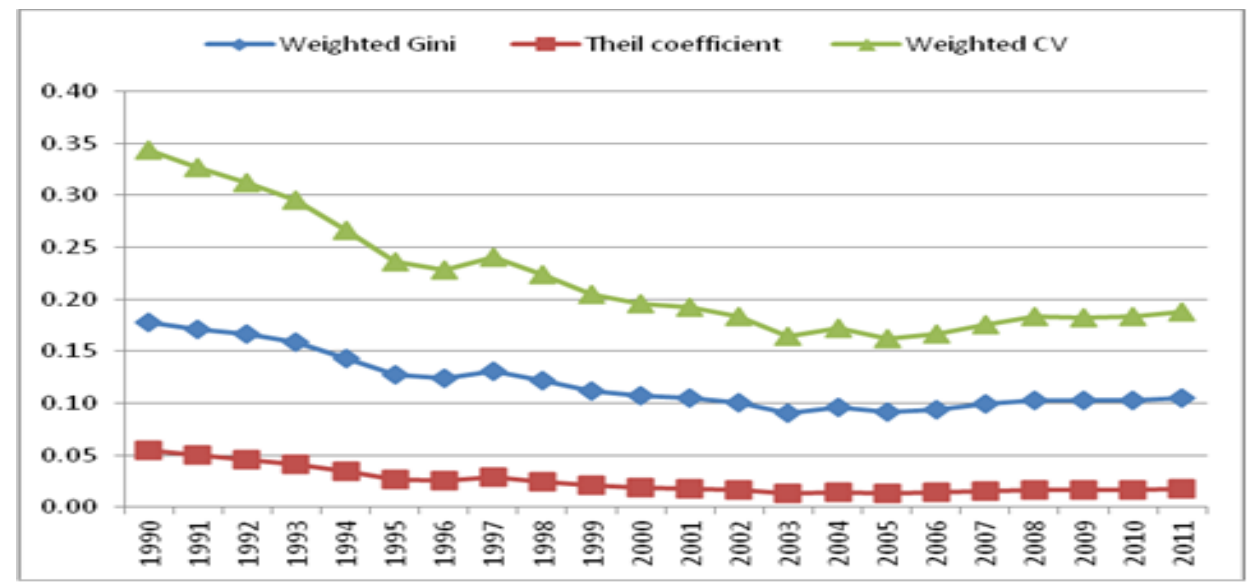

Figure 9: Coefficient of variation $\left(\mathrm{CV}_{\mathrm{W}}\right)$, Theil coefficient and Gini coefficient of GDP per capita at 1994 price of the sub-group 5

(Source: Authors' calculation)

Table 6 shows that a majority of provinces of sub-group 5 had very low ranking of GDP per capita. In 2011, the rankings of GDP per capita of Ha Giang, Lai Chau-Dien Bien and Back Giang were $61 / 61,60 / 61$ and 59/61, respectively. In the same year, almost all provinces of this sub-group had high percentage of agriculture, forestry and fishery to GDP. Of particular interest is that the percentage of overseas exports to GDP of Dak Nong-Dak Lak was high, for example roughly 53\% in 2011. This was because the province has been in a strong position of coffee production. In addition, all provinces of sub-group 5, especially Ha Giang, Lai Chau-Dien Bien and Hoa Binh, were significant recipients in terms of subsidies from the central government. For example, in 2011 the transfers per capita at 1994 prices from the central government to Ha Giang and Lai Chau-Dien Bien were approximately VND 2,182 thousand and VND 2,069 thousand, accounting for 57\% and 53\% of their GDP per capita, respectively.

Table 6: A set of economic indicators of provinces of augmented sub-group 5

\begin{tabular}{|c|c|c|c|c|c|c|}
\hline$\left.\right|^{\text {Provinces }}$ & $\begin{array}{l}\text { GDP per } \\
\text { capita in } \\
2011 \text { at } \\
1994 \text { price } \\
\text { (VND } \\
\text { thousand) }\end{array}$ & $\begin{array}{l}\text { Ranking of } \\
\text { provincial } \\
\text { GDP per } \\
\text { capita in } \\
\text { Vietnam in } \\
2011\end{array}$ & $\begin{array}{l}\text { Population } \\
\text { in } 2011 \\
\text { (Thousand) }\end{array}$ & $\begin{array}{c}\text { Percentage } \\
\text { of } \\
\text { agriculture, } \\
\text { forestry and } \\
\text { fishery to } \\
\text { GDP in } 2011 \\
(\%)\end{array}$ & $\begin{array}{c}\text { Percentage } \\
\text { of overseas } \\
\text { exports to } \\
\text { GDP in } 2011 \\
(\%)\end{array}$ & $\begin{array}{c}\text { Transfers } \\
\text { per capita } \\
\text { in } 2011 \text { at } \\
1994 \text { price } \\
\text { (VND } \\
\text { thousand) }\end{array}$ \\
\hline Lai Chau-Dien Bien & $3,869.42$ & 60 & 903.50 & 32.62 & 6.37 & $2,069.53$ \\
\hline Hoa Binh & $5,512.74$ & 53 & 799.80 & 20.76 & 7.46 & $1,725.35$ \\
\hline Ha Giang & $3,824.47$ & 61 & 746.30 & 32.12 & 3.86 & $2,181.89$ \\
\hline Bac Giang & $4,271.87$ & 59 & $1,574.30$ & 31.39 & 22.43 & 628.10 \\
\hline Quang Binh & $4,649.56$ & 57 & 853.00 & 21.07 & 11.43 & 668.51 \\
\hline Quang Tri & $5,463.34$ & 54 & 604.70 & 27.89 & 7.13 & 864.29 \\
\hline Dak Nong-Dak Lak & $6,288.67$ & 41 & $2,288.10$ & 55.32 & 53.41 & 631.62 \\
\hline Ninh Thuan & $5,864.67$ & 49 & 569.00 & 43.06 & 19.27 & 834.48 \\
\hline Vietnam & $10,550.10$ & & $1,431.18$ & 22.02 & 70.05 & 365.67 \\
\hline
\end{tabular}

(Source: Authors' calculation)

The results of time series tests (Appendix A) indicate that from 1990 to 1994, all provinces of subgroup 5 diverged downward from HCMC. Between 1995 and 2003, Lai Chau-Dien Bien, Hoa Binh, Dak Nong-Dak Lak and Ninh Thuan kept falling behind, while only Ha Giang tended to converge upward. However, from 2005 to 2011, all provinces of this sub-group tended to converge with HCMC. 
In the relation to the national average, the results of time-series regressions (Appendix B) show that between 1990 and 1994 all provinces of sub-group 5 diverged downward. In addition, during the sub-period 1995-2003, seven of the eight provinces of this sub-group (excluding Ha Giang) kept falling behind. For the last sub-period 2004-2011, only Hoa Binh and Quang Tri tended to converge upward, while Lai Chau-Dien Bien, Bac Giang, Quang Binh and Ninh Thuan continued falling behind from the national average.

An analysis of ratios of GDP per capita of each province in sub-group 5 to the national average $\left(\frac{y_{i t}}{y_{t}^{*}}\right)$

suggests that all provinces of this sub-group have been poorest performers. For example, Figure 10 indicates that, the national average is presented by a horizontal line at $100 \%$, while Dak Nong DakLak is shown as most clearly falling behind from the national average, from approximately $120 \%$ of the national average in 1990 to $60 \%$ in 2011 . Similarly, the ratio of GDP per capita of Lai Chau - Dien Bien relative to the national average decreased dramatically from $75 \%$ in 1990 to $37 \%$ in 2011. Also, this Figure indicates that Quang Binh, Ninh Thuan and Bac Giang have been very poor performing provinces. One of the main reasons causing poor performances of these provinces is that they tend to be located in remote, mountainous areas (including Lai Chau - Dien Bien, Ha Giang and Bac Giang) or are not well connected to strong economic hubs (comprising Hoa Binh, Quang Binh, Quang Tri, Dak Nong-Dak Lak, and Ninh Thuan).

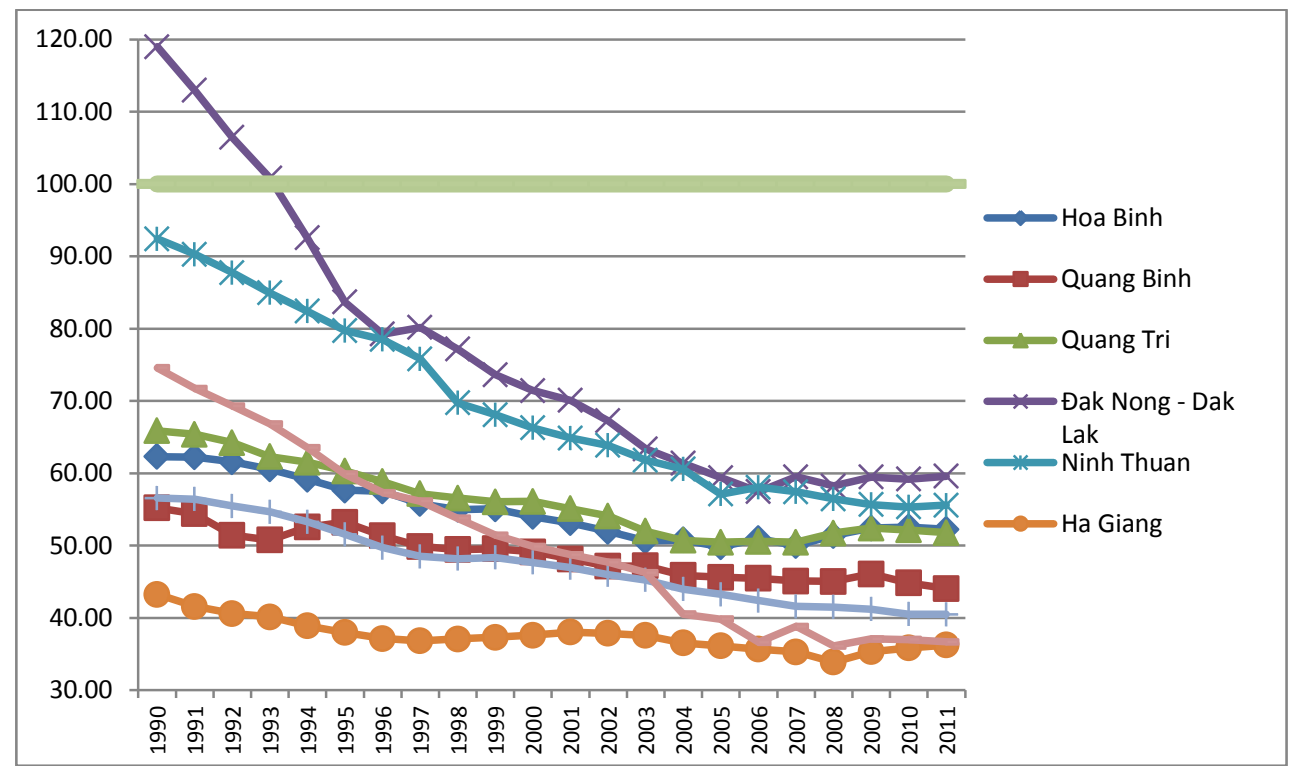

Figure 10: GDP per capita of poor performing provinces in sub-group 5 relative to the national average (the national average $=100$ )

(Source: Authors' calculation)

\section{CONCLUSIONS}

This study analyses trends and patterns of inequality in provincial GDP per capita of each of the five sub-groups of provinces in Vietnam during the period 1990-2011, and the growth path of each province compared with that of the reference economy (HCMC and the national average). The results of using coefficient of variation, Theil index and Gini coefficient show the downward trends of inequality in GDP per capita of each sub-group. The findings also indicate that during the 19901994, most provinces diverged from Ho Chi Minh City but during the sub-period 2004-2011, all provinces tended to converge to it. The results show the fostering role and positive spill-overs from the economic centres to their surrounding provinces in sub-group 1. However, there were few poorest provinces in sub-group 5, which tend to be located in geographically and economically isolated regions of Vietnam. Our findings also suggest that main factors contributing to the 
downward trends of inequality in GDP per capita among sub-groups of provinces in Vietnam during the period 1990-2011 include FDI, public investment and transfers from the central government to poor provinces. This study recommends three policy implications. First, it is worth promoting further positive spillovers of the existing economic centres (the dynamic cities/provinces) on their adjacent provinces. Second, the central government should pay more attention to the poorest provinces through its investment policies and budget transfer mechanism from central to provincial governments in order to safeguard their socio-economic development. Third, economic efficiencies in public expenditure programs, therefore, is a primary determinant of the success of past economic growth in reducing regional disparity.

\begin{tabular}{|l|}
\hline Funding: This study received no specific financial support. \\
\hline Competing Interests: The authors declare that they have no conflict of interests. \\
\hline Contributors/Acknowledgement: All authors participated equally in designing and estimation of current \\
research. \\
\hline Views and opinions expressed in this study are the views and opinions of the authors, Asian Journal of \\
Empirical Research shall not be responsible or answerable for any loss, damage or liability etc. caused in \\
relation to/arising out of the use of the content.
\end{tabular}

\section{References}

Apergis, N., Panopoulou, E., \& Tsoumas, C. (2010). Old wine in a new bottle: Growth convergence dynamics in the EU. Atlantic Economic Journal, 38(2), 169-181.

Barro, R. J., \& Sala-i-Martin, X. (1991). Convergence across states and regions. Brooking Papers on Economic Activity, 1, 107-182.

Bartkowska, M., \& Riedl, A. (2012). Regional convergence clubs in Europe: Identification and conditioning factors. Economic Modelling, 29(1), 22-31.

Carlino, G., \& Mills, L. (1996). Convergence and the U.S. states: A time-series analysis. Journal of Regional Science, 36(4), 597-616.

Chang, G. H. (2002). The cause and cure of China's widening income disparity. China Economic Review, 13(4), 335-340.

Chow, G. C. (1960). Tests of equality between sets of coefficients in two linear regressions. Econometrica, 28, 591-665.

Dollar, D. (2002). Reform, growth and poverty in Vietnam. World Bank, Washington, D.C.

Garcia, J. G., \& Soelistianingsih, L. (1998). Why do differences in provincial incomes persist in Indonesia?. Bulletin of Indonesian Economic Studies, 34(1), 95-120.

Genc, I. H., Miller, J. R., \& Rupasingha, A. (2011). Stochastic convergence tests for US regional per capita personal income; some further evidence: A research note. The Annals of Regional Science, 46(2), 369-377.

Gen, Y. L. (1999). China's changing regional disparities during the reform period. Economic Geography, 75(1), 59-70.

Herrerias, M. J., \& Ordonez, J. (2012). New evidence on the role of regional clusters and convergence in China (1952-2008). China Economic Review, 23(4), 1120-1133.

Jian, T., Sachs, J. D., \& Warner, A. M. (1996). Trends in regional inequality in China. China Economic Review, 7(1), 1-21.

Kakwani, N. C. (1980). Inequality and poverty - methods of estimation and policy applications, World Bank, Oxford University Press.

Kharisma, B., \& Saleh, S. (2013). Convergence of income among provinces in Indonesia, 19842008: a panel data approach. Journal of Indonesian Economy and Business, 28(2), 167-187.

Le, K. Q. (2003). An assessment of spatial differentiation in Vietnam's social-economic development 1990-2000. University of Akron, Department of Public Administration and Urban Affairs.

Le, T. H., \& Booth, A. L. (2013). Inequality in Vietnamese urban-rural living standards, 1993-2006. Review of Income and Wealth, 60(4), 862-886.

Liu, A. Y. C. (2001). Markets, inequality and poverty in Vietnam. Asian Economic Journal, 15(2), 217-35. 
Liu, A. Y. C. (2008). Changes in urban inequality in Vietnam: 1992-1998. Economic Systems, 32, 410-425.

Loewy, M. B., \& Papell, D. H. (1996). Are US regional incomes converging? Some further evidence. Journal of Monetary Economics, 38(3), 587-598.

Malesky, E., \& London, J., (2014). The political economy of development in China and Vietnam. Annual Review of Political Science, 17, 395-419.

Narayan, P. K. (2008). Evidence of panel stationarity from Chinese provincial and regional income. China Economic Review, 19(2), 274-286.

Neri, F. (1998). The economic performance of the states and territories of Australia: 1861-1992. The Economic Record, 74(225), 105-120.

Nguyen, D. T., Smith, C., \& Meyer-Boehm, G. (2006). Growth and divergence in output per capita and labour productivity among the states of Australia, 1984-85 to 2004-05, Department of Accounting, Finance, and Economics, Griffith University, Australia.

Nguyen, H. H. (2009). Regional welfare disparities and regional economic growth in Vietnam. Wageningen University.

Pedroni, P., \& Yao, J. Y. (2006). Regional income divergence in China. Journal of Asian Economics, 17(2), 294-315.

Phillips, P. C., \& Sul, D. (2007). Transition modelling and econometric convergence tests. Econometrica, 75(6), 1771-1855.

Phillips, P. C., \& Sul, D. (2009). Economic transition and growth. Journal of Applied Econometrics, 24(7), 1153-1185.

Resosudarmo, B. P., \& Vidyattama, Y. (2006). Regional income disparity in Indonesia: A panel data analysis. ASEAN Economic Bulletin, 23(1), 31-44.

Sala-i-Martin, X. X. (1996). Regional cohesion: Evidence and theories of regional growth and convergence. European Economic Review, 40(6), 1325-1352.

Shankar, R., \& Shah, A. (2003). Bridging the economic divide within countries: A scorecard on the performance of regional policies in reducing regional income disparities. World Development, 31(8), 1421-1441.

Smith, C. (2004). For richer or poorer: recent trends in Australia's regional income dynamics. Australasian Journal of Regional Studies, 10(2), 195-223.

Takahashi, K. (2007). Sources of regional income disparity in rural Vietnam: Oaxaca-Blinder Decomposition (No. 95), Institute of Developing Economies.

Theil, H. (1967). Economics and information theory. North-Holland Publishing Company, Amsterdam, Netherlands.

Vu, X. B. (2015). Disparities and growth within APEC countries, 1990 2011. Journal of Economic Integration, 30(3), 399-428.

Vu, X. B., Nguyen, D. T., Nghiem, H. S., \& Hoang, V. N. (2016). Provincial divergence and subgroup convergence in Vietnam's GDP per capita: 1990 - 2011. Journal of Asian Economics, (under review).

Walle, D., \& Gunewardena, D. (2001). Sources of ethnic inequality in Viet Nam. Journal of Development Economics, 65(1), 177-207.

Williamson, J. G. (1965). Regional inequality and the process of national development: A description of the patterns. Economic Development and Cultural Change, 13(2), 1-84.

World Bank (2016). World Bank indicators. Washington, D.C. http://data.worldbank.org/indicator (accessed July 30, 2016). 
Appendix A: The growth path of each province compared with that of Ho Chi Minh City

* indicates significant at 10\%; ** indicates significant at 5\%; *** indicates significant at

\begin{tabular}{|c|c|c|c|c|c|c|c|}
\hline Provinces & Sub-group & $a_{1}$ & $\mathbf{a}_{2}$ & $\mathbf{a}_{3}$ & $b_{1}$ & $\mathbf{b}_{2}$ & $\mathbf{b}_{3}$ \\
\hline Quang Ninh & 1 & $* * *-0.88$ & $* * *-0.15$ & $*_{-0.04}$ & $* * *-0.05$ & $* * * 0.05$ & $* * * 0.04$ \\
\hline Hanoi & 1 & $* * *-0.31$ & -0.02 & 0.01 & 0.004 & 0.001 & $* * * 0.02$ \\
\hline Hai Phong & 1 & $* * *-0.77$ & $* * *-0.08$ & 0.002 & 0.01 & $* * * 0.01$ & $* * * 0.04$ \\
\hline Hai Duong & 1 & $* * *-1.04$ & $* * *-0.09$ & -0.02 & $* * *-0.03$ & $* * * 0.01$ & $* * * 0.03$ \\
\hline Hung Yen & 1 & $* * *-1.21$ & $* * *-0.16$ & -0.04 & $* * *-0.04$ & $* * * 0.04$ & $* * * 0.05$ \\
\hline Ninh Binh & 1 & $* * *-1.41$ & $* * *-0.11$ & -0.02 & $* * *-0.03$ & 0.01 & $* * * 0.1$ \\
\hline Vinh Phuc & 1 & $* * *-1.54$ & $* * *-0.15$ & $* *_{-0.09}$ & $* *_{-} 0.03$ & $* * * 0.08$ & $* * * 0.11$ \\
\hline Bac Ninh & 1 & $* * *-1.33$ & $* * *-0.17$ & $* * *-0.10$ & $* * *-0.05$ & $* * * 0.06$ & $* * * 0.07$ \\
\hline Đa Nang & 1 & $* * *-0.67$ & -0.04 & -0.02 & $* * *-0.02$ & $* * * 0.02$ & $* * * 0.03$ \\
\hline Quang Ngai & 1 & $* * *-1.41$ & -0.09 & $* * *-0.19$ & $* *-0.04$ & 0.004 & $* * * 0.1$ \\
\hline Khanh Hoa & 1 & $* * *-0.59$ & $* * *-0.09$ & -0.03 & $* * *-0.04$ & 0.002 & $* * * 0.03$ \\
\hline Lam Đong & 1 & $* * *-0.91$ & $* 0.11$ & 0.01 & -0.02 & $* * *-0.03$ & $* * * 0.07$ \\
\hline Tay Ninh & 1 & $* * *-0.96$ & $* * *-0.12$ & -0.01 & $* * *-0.04$ & $* * * 0.04$ & $* * * 0.06$ \\
\hline Binh Duong & 1 & $* * *-0.66$ & $* * *-0.10$ & -0.01 & $*_{*} *_{-0.02}$ & $* * * 0.03$ & $* * * 0.02$ \\
\hline Dong Nai & 1 & $* * *-0.79$ & $* * *-0.06$ & 0.01 & *0.01 & $* * * 0.02$ & $* * * 0.03$ \\
\hline Binh Thuan & 1 & $* * *-1.39$ & $* *-0.08$ & -0.03 & $* * *-0.04$ & $* 0.01$ & $* * * 0.07$ \\
\hline Long An & 1 & $* * *-0.73$ & $* * *-0.09$ & $* *_{-0.06}$ & $* * *-0.03$ & $*_{-0.01}$ & $* * * 0.04$ \\
\hline Đong Thap & 1 & $* * *-1.04$ & $* * *-0.1$ & $*_{*} *_{-0.07}$ & -0.01 & $*^{*} *_{-0.01}$ & $* * * 0.07$ \\
\hline Kien Giang & 1 & $* * *-0.44$ & $* * *-0.15$ & -0.05 & $* * *-0.05$ & 0.001 & $* * * 0.04$ \\
\hline Can Tho-Hau Giang & 1 & $* * *-1.21$ & $* * *-0.12$ & -0.01 & $* * *-0.03$ & $* * * 0.02$ & $* * * 0.07$ \\
\hline Tra Vinh & 1 & $* * *-0.94$ & $* * *-0.11$ & -0.03 & $* * *-0.04$ & 0.004 & $* * * 0.06$ \\
\hline Soc Trang & 1 & $* * *-0.89$ & $* * *-0.08$ & $*_{-} *_{-0.05}$ & $* * *-0.03$ & $* * * 0.01$ & $* * * 0.04$ \\
\hline Bac Lieu & 1 & $* * *-0.98$ & $* * *_{-}-0.22$ & 0.05 & $*_{-0.03}$ & $* * * 0.04$ & $* * * 0.03$ \\
\hline $\mathrm{Ca} \mathrm{Mau}$ & 1 & $* * *-0.54$ & $* * *-0.15$ & -0.06 & $* * *-0.05$ & 0.004 & $* * * 0.06$ \\
\hline Ba Ria Vung Tau & 1 & $* * * 0.98$ & $* * *-0.14$ & 0.04 & $*_{-} 0.02$ & $* * * 0.04$ & $* * *-0.02$ \\
\hline Cao Bang & 2 & $* * *-1.54$ & $* * *-0.08$ & $* * *-0.07$ & $* *_{-} 0.02$ & $* * * 0.02$ & $* * * 0.04$ \\
\hline Tuyen Quang & 2 & $* * *-1.32$ & $* * * 0.01$ & $* * 0.06$ & $* * *-0.05$ & 0.01 & $* * * 0.06$ \\
\hline $\mathrm{Ha} \mathrm{Nam}$ & 2 & $* * *-1.21$ & $* * *-0.15$ & $* *_{-} 0.13$ & $* *_{-} 0.03$ & 0.01 & $* * * 0.07$ \\
\hline Thanh Hoa & 2 & $* * *-1.31$ & $* *_{-}-0.11$ & $* * *-0.13$ & $* * *-0.04$ & $* * 0.01$ & $* * * 0.06$ \\
\hline Quang Nam & 2 & $* * *-1.29$ & $* * *-0.10$ & $*_{*}-0.07$ & $* * *-0.03$ & -0.001 & $* * * 0.06$ \\
\hline An Giang & 2 & $* * *-0.88$ & $* *_{-} 0.08$ & -0.05 & $* *-0.02$ & $*_{-0} 0.01$ & $* * * 0.04$ \\
\hline Vinh Long & 2 & $* * *-1.01$ & $* *-0.08$ & $* *-0.07$ & $* *-0.02$ & $*_{-0.01}$ & $* * * 0.05$ \\
\hline Ben Tre & 2 & $* * *-0.84$ & $*_{-}-0.08$ & -0.05 & $* * *-0.04$ & $*_{-0}-0.01$ & $* * * 0.04$ \\
\hline Thai Binh & 2 & $* * *-0.93$ & $* *-0.09$ & $* *_{-} 0.10$ & $* * *-0.04$ & $* * *_{-} 0.03$ & $* * * 0.05$ \\
\hline Tien Giang & 2 & $* * *-0.91$ & $* * *-0.10$ & $* * *-0.08$ & $* * *-0.03$ & 0.003 & $* * * 0.04$ \\
\hline Lang Son & 3 & $* * *-1.24$ & $* *_{-} 0.07$ & $*_{-0}-0.06$ & $* * *-0.03$ & $* * * 0.01$ & $* * * 0.04$ \\
\hline Thua Thien Hue & 3 & $* * *-1.34$ & $* * *-0.12$ & $* * *-0.11$ & $* * *-0.04$ & $* * * 0.01$ & $* * * 0.06$ \\
\hline Binh Đinh & 3 & $* * *-1.26$ & -0.01 & $* *-0.08$ & $* * *-0.03$ & -0.0002 & $* * * 0.05$ \\
\hline Son La & 4 & $* * *-1.78$ & $* *_{-}-0.10$ & -0.02 & $* *_{-} 0.03$ & -0.002 & $* * * 0.06$ \\
\hline Lao Cai & 4 & $* * *-1.19$ & $* * *-0.22$ & 0.07 & $* * *-0.06$ & $*_{-} 0.01$ & $* * * 0.05$ \\
\hline Bac Kan & 4 & $* * *-1.39$ & $* * *-0.20$ & $*_{-} 0.07$ & $* * *-0.07$ & $* * 0.01$ & $* * * 0.05$ \\
\hline Yen Bai & 4 & $* * *-1.38$ & $* * *-0.09$ & $* * *-0.10$ & $* * *-0.05$ & $* 0.01$ & $* * * 0.05$ \\
\hline Thai Nguyen & 4 & $* * *-1.31$ & -0.04 & $* * *_{-}-0.11$ & $* * *-0.05$ & $* * * 0.02$ & $* * * 0.04$ \\
\hline Phu Tho & 4 & $* * *-1.27$ & $* * *-0.13$ & $*_{*} *_{-0.07}$ & $* * *-0.04$ & $* * * 0.01$ & $* * * 0.04$ \\
\hline Ha Tay & 4 & $* * *-1.18$ & $* * *-0.12$ & 0.01 & $* * *-0.04$ & 0.01 & $* * * 0.02$ \\
\hline Nam Đinh & 4 & $* * *-1.12$ & $*_{*}-0.09$ & $* * *-0.10$ & $* * *-0.04$ & $* *_{-0.01}$ & $* * * 0.05$ \\
\hline Nghe An & 4 & $* * *-1.27$ & $* * *-0.16$ & $*_{-0.06}$ & $* * *-0.03$ & $* * 0.01$ & $* * * 0.04$ \\
\hline Ha Tinh & 4 & $* * *-1.33$ & $* * *-0.11$ & $* *_{-0} 0.08$ & $* * *-0.03$ & 0.004 & $* * * 0.05$ \\
\hline Phu Yen & 4 & $* * *-1.32$ & $* * *_{-}-0.1$ & $* * *-0.07$ & $* * *-0.05$ & 0.002 & $* * * 0.05$ \\
\hline Kon Tum & 4 & $* * *-0.99$ & $* * *-0.17$ & $* * *-0.15$ & $* * *-0.06$ & $* 0.01$ & $* * * 0.04$ \\
\hline
\end{tabular}




\begin{tabular}{|c|c|c|c|c|c|c|c|}
\hline Gia Lai & 4 & $* * *-1.2$ & $* * *-0.1$ & -0.01 & $* * *_{-} 0.06$ & -0.0005 & $* * * 0.03$ \\
\hline Binh Phuoc & 4 & $* * *_{-} 1.2$ & $* *_{-0.08}$ & 0.04 & $* *_{*}-0.01$ & $* *_{*}-0.01$ & $* * * 0.04$ \\
\hline Hoa Binh & 5 & $* * *-1.32$ & $* * *-0.09$ & $*_{-}-0.07$ & $* * *-0.04$ & $* * *-0.01$ & $* * * 0.05$ \\
\hline Quang Binh & 5 & $* * *-1.46$ & -0.05 & $*_{-0.05}$ & $* * *_{-} 0.04$ & -0.004 & $* * * 0.03$ \\
\hline Quang Tri & 5 & $* * *-1.27$ & $* * *-0.11$ & $* * *-0.09$ & $* * *_{-} 0.04$ & -0.01 & $* * * 0.04$ \\
\hline Dak Nong-Dak Lak & 5 & $* * *_{-}-0.63$ & $* * *-0.16$ & $* * *_{-}-0.12$ & $* * *_{-}-0.09$ & $* * *_{-}-0.02$ & $* * * 0.04$ \\
\hline Ninh Thuan & 5 & $* * *_{-} 0.92$ & $* * *_{-} 0.09$ & $*_{-} 0.06$ & $* * *_{-} 0.05$ & $* * *_{-} 0.02$ & $* * * 0.03$ \\
\hline Ha Giang & 5 & $* * *-1.69$ & $* * *_{-} 0.13$ & $* * *-0.09$ & $* * *_{-} 0.05$ & $* * * 0.01$ & $* * * 0.04$ \\
\hline Bac Giang & 5 & $* * *-1.42$ & $* * *-0.13$ & $* *_{-} 0.07$ & $* * *-0.04$ & -0.004 & $* * * 0.03$ \\
\hline Lai Chau-Dien Bien & 5 & $* * *-1.12$ & $* * *-0.12$ & $* * *-0.17$ & $* * *_{-} 0.06$ & $* * *_{-} 0.02$ & $* * * 0.03$ \\
\hline
\end{tabular}

Source: Authors' calculation

Appendix B: The growth path of each province compared with the national average

* indicates significant at 10\%; ** indicates significant at 5\%; *** indicates significant at $1 \%$

\begin{tabular}{|c|c|c|c|c|c|c|c|}
\hline Provinces & Sub-group & a1 & a2 & a3 & b1 & b2 & b3 \\
\hline Quang Ninh & 1 & $* * * 0.04$ & $* * *_{-} 0.07$ & -0.003 & $* * *-0.03$ & $* * * 0.04$ & $* * 0.0046$ \\
\hline Hanoi & 1 & $* * * 0.56$ & $* * * 0.06$ & $* * * 0.05$ & $* * * 0.02$ & $* * *-0.01$ & $* * *-0.02$ \\
\hline Hai Phong & 1 & $* * * 0.1$ & 0.001 & $* * 0.04$ & $* * * 0.03$ & 0.0009 & -0.001 \\
\hline Hai Duong & 1 & $* * *-0.17$ & -0.01 & 0.02 & $* * *-0.01$ & $* * 0.0047$ & $* * *_{-} 0.01$ \\
\hline Hung Yen & 1 & $* * *-0.32$ & $* * *-0.07$ & 0.0006 & $* * *-0.01$ & $* * * 0.03$ & $* * * 0.01$ \\
\hline Ninh Binh & 1 & $* * *_{-} 0.53$ & -0.02 & 0.02 & $* * *-0.01$ & $*_{-0.0044}$ & $* * * 0.06$ \\
\hline Vinh Phuc & 1 & $* * *-0.66$ & $*_{-0.06}$ & $*_{-0.05}$ & $* * *-0.01$ & $* * * 0.07$ & $* * * 0.07$ \\
\hline Bac Ninh & 1 & $* * *-0.46$ & $* * *_{-} 0.08$ & $* *_{-} 0.06$ & $* * *-0.02$ & $* * * 0.05$ & $* * * 0.04$ \\
\hline Đa Nang & 1 & $* * * 0.21$ & 0.04 & 0.02 & -0.0002 & $* * * 0.01$ & $* * *_{-}-0.01$ \\
\hline Quang Ngai & 1 & $* * *-0.53$ & -0.005 & $* *-0.15$ & $* * *-0.02$ & $* * *-0.01$ & $* * * 0.06$ \\
\hline Khanh Hoa & 1 & $* * * 0.28$ & -0.01 & 0.005 & $* * *-0.01$ & $* * *_{-} 0.01$ & $* * *_{-} 0.01$ \\
\hline Lam Đong & 1 & $* * *-0.03$ & $* * 0.2$ & 0.05 & 0.0008 & $* * *-0.04$ & $* * * 0.03$ \\
\hline Ho Chi Minh City & 1 & $* * * 0.87$ & $* * * 0.08$ & $* 0.04$ & $* * * 0.02$ & $* * *_{-} 0.01$ & $* * *-0.04$ \\
\hline Tay Ninh & 1 & $* * *-0.09$ & $* * *_{-}-0.04$ & 0.02 & $* * *-0.02$ & $* * * 0.03$ & $* * * 0.03$ \\
\hline Binh Duong & 1 & $* * * 0.22$ & -0.01 & 0.03 & $* * * 0.0035$ & $* * * 0.02$ & $* * *_{-}-0.02$ \\
\hline Dong Nai & 1 & $* * * 0.08$ & $* 0.03$ & $* 0.05$ & $* * * 0.03$ & $* * * 0.01$ & -0.005 \\
\hline Binh Thuan & 1 & $* * *-0.52$ & 0.004 & 0.01 & $* * *_{-} 0.01$ & -0.001 & $* * * 0.03$ \\
\hline Long An & 1 & $* * * 0.14$ & -0.01 & $*_{*}-0.02$ & -0.01 & $* *_{-} 0.02$ & 0.0025 \\
\hline Đong Thap & 1 & $* * *-0.17$ & -0.02 & $* * *_{-}-0.03$ & $* * * 0.02$ & $* * *-0.02$ & $* * * 0.03$ \\
\hline Kien Giang & 1 & $* * * 0.43$ & $* * *_{-} 0.07$ & -0.02 & $* * *-0.03$ & $* * *_{-} 0.01$ & $* * * 0.01$ \\
\hline Can Tho-Hau Giang & 1 & $* * *_{-} 0.34$ & $* *_{-} 0.04$ & 0.02 & $* * *-0.01$ & $* 0.01$ & $* * * 0.03$ \\
\hline Tra Vinh & 1 & $* * *_{-} 0.07$ & $* *_{-} 0.03$ & 0.01 & $* * *_{-} 0.01$ & $* * *_{-} 0.01$ & $* * * 0.02$ \\
\hline Soc Trang & 1 & $* * *-0.03$ & -0.001 & -0.01 & $* * *-0.01$ & -0.0003 & 0.002 \\
\hline Bac Lieu & 1 & $* * *_{-} 0.11$ & $* *_{-} 0.14$ & $* * 0.09$ & $* * *_{-} 0.01$ & $* * * 0.03$ & $* * *_{-}-0.01$ \\
\hline $\mathrm{Ca} \mathrm{Mau}$ & 1 & $* * * 0.34$ & $*_{*}-0.07$ & -0.02 & $* * *-0.03$ & -0.006 & $* * * 0.02$ \\
\hline Ba Ria-Vung Tau & 1 & $* * * 1.86$ & $*_{-0.05}$ & $* * * 0.08$ & 0.001 & $* * * 0.03$ & $* * *-0.06$ \\
\hline Cao Bang & 2 & $* * *-0.67$ & 0.01 & $* *_{-} 0.03$ & $* * 0.01$ & $* * * 0.01$ & $* 0.0028$ \\
\hline Tuyen Quang & 2 & $* * *-0.45$ & $* * *_{-}-0.04$ & -0.04 & $* * *-0.02$ & $*_{-0.0034}$ & $* * * 0.02$ \\
\hline $\mathrm{Ha} \mathrm{Nam}$ & 2 & $* * *_{-} 0.33$ & $* *_{-} 0.07$ & $* * *_{-}-0.1$ & $* * *_{-} 0.01$ & -0.002 & $* * * 0.03$ \\
\hline Thanh Hoa & 2 & $* * *-0.44$ & $*_{-0.03}$ & $* * *_{-}-0.1$ & $* * *-0.02$ & 0.004 & $* * * 0.02$ \\
\hline Quang Nam & 2 & $* * *-0.42$ & $*_{-}-0.01$ & $* * *_{-} 0.03$ & $*_{-0.0029}$ & $* * *_{-} 0.01$ & $* * * 0.02$ \\
\hline An Giang & 2 & $* *-0.01$ & -0.0007 & -0.01 & $* * 0.0017$ & $* *_{-} 0.02$ & -0.00007 \\
\hline Vinh Long & 2 & $* * *-0.13$ & 0.003 & $* * *_{-}-0.04$ & $* * * 0.0041$ & $* * *-0.02$ & $* * * 0.01$ \\
\hline Ben Tre & 2 & $* * * 0.04$ & 0.01 & -0.01 & $* * *-0.02$ & $* * *-0.02$ & 0.002 \\
\hline Thai Binh & 2 & $* * *-0.06$ & -0.01 & $* *-0.06$ & $* * *-0.02$ & $* * *-0.04$ & $* * * 0.02$ \\
\hline Tien Giang & 2 & $* * *-0.04$ & -0.01 & $* * *_{-}-0.05$ & $* *_{-}-0.01$ & $* * *-0.01$ & $* * * 0.0044$ \\
\hline
\end{tabular}




\begin{tabular}{|c|c|c|c|c|c|c|c|}
\hline$\overline{\text { Lang Son }}$ & 3 & $* * *-0.37$ & 0.01 & $* * *-0.03$ & $* * *_{-} 0.01$ & $* * * 0.0026$ & $* *_{-} 0.0027$ \\
\hline Thua Thien Hue & 3 & $* * *-0.47$ & $* * *-0.04$ & $* * *-0.08$ & $* * *-0.02$ & 0.002 & $* * * 0.02$ \\
\hline Binh Đinh & 3 & $* * *_{-}-0.39$ & $* 0.07$ & $* * *-0.04$ & -0.01 & $* * *-0.01$ & $* * * 0.01$ \\
\hline Son La & 4 & $* * *-0.9$ & -0.01 & 0.01 & -0.0039 & $* * *-0.01$ & $* * * 0.02$ \\
\hline Lao Cai & 4 & $* * *-0.32$ & $* *_{-} 0.14$ & $* * * 0.11$ & $* * *-0.04$ & $* * *-0.02$ & $* * * 0.01$ \\
\hline Bac Kan & 4 & $* * *-0.53$ & $* * *-0.11$ & -0.03 & $* * *-0.05$ & 0.0023 & $* * * 0.02$ \\
\hline Yen Bai & 4 & $* * *-0.51$ & -0.01 & $* * *-0.07$ & $* * *-0.02$ & $*_{-0.0025}$ & $* * 0.01$ \\
\hline Thai Nguyen & 4 & $* * *-0.44$ & 0.04 & $* * *-0.07$ & $* * *-0.02$ & 0.006 & -0.003 \\
\hline Phu Tho & 4 & $* * *-0.4$ & $* * *-0.04$ & $* * *-0.03$ & $* * *-0.02$ & $* 0.0028$ & -0.0008 \\
\hline Ha Tay & 4 & $* * *_{-}-0.31$ & $* *_{-0.04}$ & 0.05 & $* * *_{-} 0.01$ & -0.004 & $* * *-0.02$ \\
\hline Nam Đinh & 4 & $* * *-0.25$ & -0.004 & $*_{*} *_{-0.06}$ & $* * *-0.01$ & $*_{-}-0.02$ & $* * 0.01$ \\
\hline Nghe An & 4 & $* * *-0.4$ & $* * *-0.07$ & $*_{-} 0.03$ & $* * *-0.01$ & 0.001 & -0.001 \\
\hline Ha Tinh & 4 & $* * *-0.45$ & $*_{-} *_{-0.02}$ & $*_{-0}-0.04$ & $* * *-0.01$ & $* * *-0.01$ & $* * * 0.01$ \\
\hline Phu Yen & 4 & $* * *-0.45$ & -0.01 & $*_{*} *_{-0.03}$ & $* * *-0.02$ & $* * *-0.01$ & $* * * 0.01$ \\
\hline Kon Tum & 4 & $* * *_{-} 0.13$ & $* * *-0.09$ & $* * *-0.11$ & $* * *-0.04$ & -0.002 & -0.001 \\
\hline Gia Lai & 4 & $* * *-0.32$ & -0.02 & $* 0.03$ & $* * *-0.04$ & $* * *-0.01$ & -0.004 \\
\hline Binh Phuoc & 4 & $* * *_{-}-0.32$ & 0.01 & $* 0.07$ & $* * *_{-} 0.03$ & $* * *-0.02$ & 0.005 \\
\hline Hoa Binh & 5 & $* * *_{-}-0.45$ & -0.01 & $* *_{-} 0.03$ & $* * *-0.01$ & $* * *-0.02$ & $* * * 0.01$ \\
\hline Quang Binh & 5 & $* * *_{-} 0.59$ & 0.03 & $*_{-} *_{-0.02}$ & $* *_{-0.02}$ & $* * *_{-} 0.01$ & $* *_{-} 0.0039$ \\
\hline Quang Tri & 5 & $* * *-0.39$ & -0.01 & $* * *-0.05$ & $* * *-0.02$ & $* * *-0.02$ & $* * * 0.01$ \\
\hline Đak Nong - Dak Lak & 5 & $* * * 0.24$ & $* * *-0.08$ & $* * *-0.08$ & $* * *-0.06$ & $* * *-0.03$ & -0.002 \\
\hline Ninh Thuan & 5 & $* * *_{-} 0.05$ & -0.004 & -0.02 & $* * *-0.03$ & $* * *-0.03$ & $* * *-0.01$ \\
\hline Ha Giang & 5 & $* * *-0.82$ & $* * *-0.04$ & $* * *-0.05$ & $* * *-0.02$ & 0.002 & -0.002 \\
\hline Bac Giang & 5 & $* * *_{-} 0.55$ & $* * *-0.04$ & $* * *-0.03$ & $* * *-0.02$ & $* * *-0.01$ & $* * *_{-} 0.01$ \\
\hline Lai Chau - Dien Bien & 5 & $* * *_{-}-0.25$ & $* * *-0.04$ & $* * *-0.13$ & $* * *-0.04$ & $* * *-0.03$ & $* * *-0.01$ \\
\hline
\end{tabular}

Source: Authors' calculation

Appendix C: The coefficient of variation $\left(C V_{W}\right)$ of GDP per capita at 1994 price: all provinces

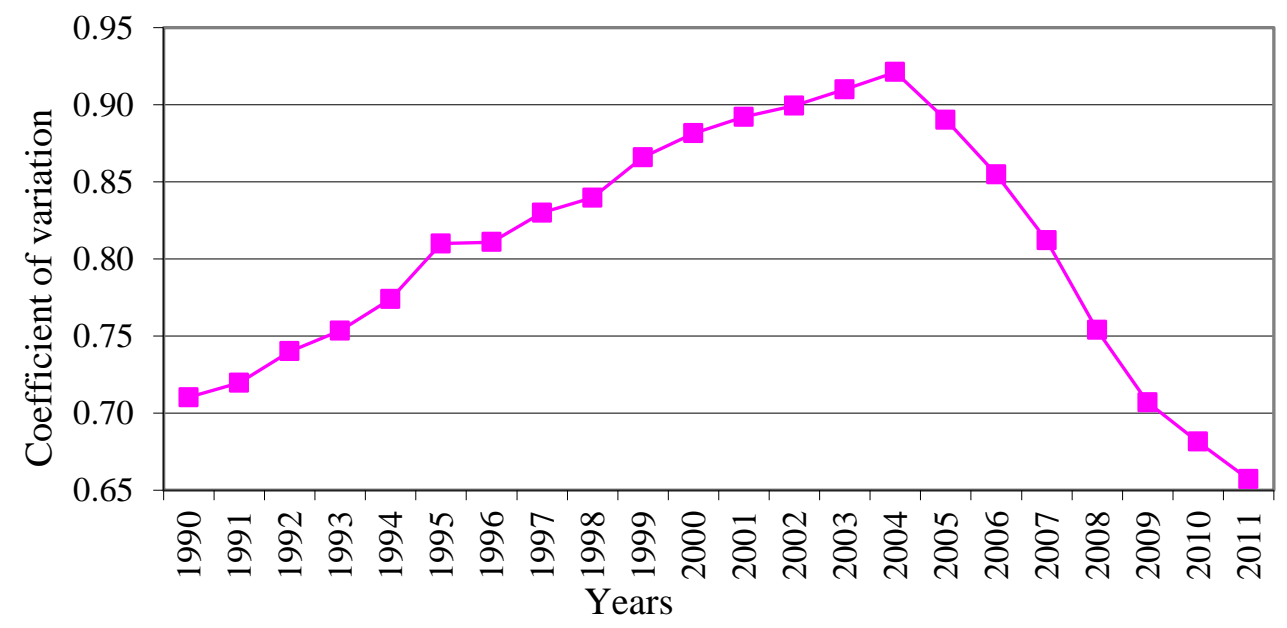

Source: Authors' calculation 